University of Redlands

\title{
Development of a Geospatial Database and Data Management Strategy for Ala Kahakai National Historic Trail, Big Island, Hawai'i
}

A Major Individual Project submitted in partial satisfaction of the requirements

for the degree of Master of Science in Geographic Information Systems

\author{
by \\ Lisa Benvenuti
}

Douglas M. Flewelling, Ph.D., Committee Chair

Russell Weaver, Ph.D.

May 2014 
Development of a Geospatial Database and Data Management Strategy for Ala Kahakai National Historic Trail, Big Island, Hawai'i

Copyright (C) 2014

by

Lisa Benvenuti 
The report of Lisa Benvenuti is approved.
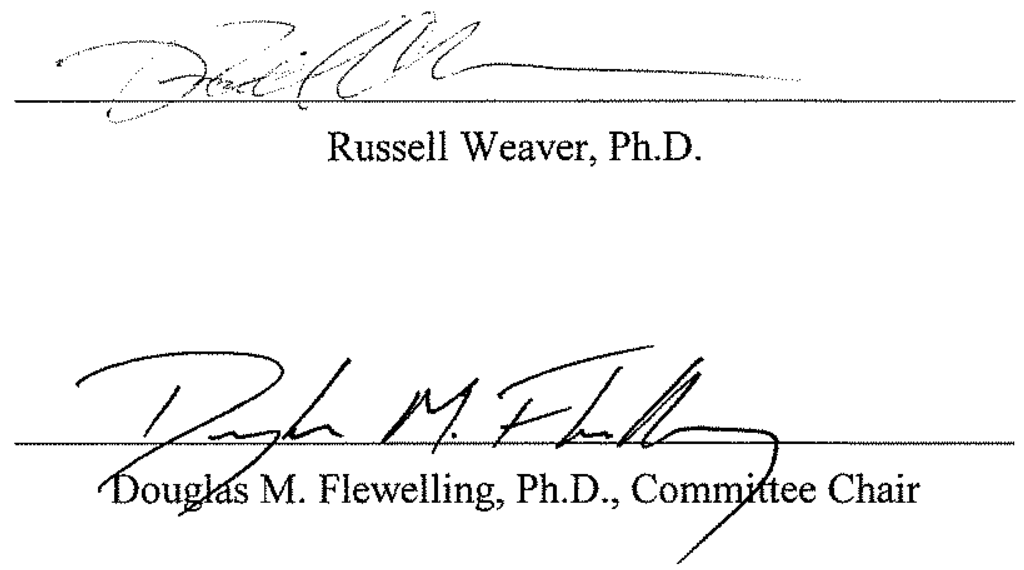

May 2014 


\section{Acknowledgements}

I would like to thank the faculty and staff of the MS GIS Program for their patience with my extended part-time status, my co-workers at the Redlands Institute for their understanding with time taken off (two of whom are in the same struggling-to-finish boat), and my amazing boss, Jordan Henk, who encouraged and prodded me as persistently as any parent.

Thank you to my parents, who frequently asked "Are you almost done?" and "Are you working on your paper this weekend?" as if I were still in grade school. They have always stood by to support me no matter what I did or how long it took.

And to Ruben who nagged, hushed, did dishes, and supported me in a hundred different ways. 



\begin{abstract}
Development of a Geospatial Database and Data Management Strategy for Ala Kahakai National Historic Trail, Big Island, Hawai' $i$

by

Lisa Benvenuti
\end{abstract}

The Ala Kahakai National Historic Trail, Big Island, Hawai' $i$ was established in 2000 to preserve and protect traditional Native Hawaiian culture and natural resources. The 175mile trail contains many sites of cultural and historical significance. This project conducted a needs assessment and compiled a data inventory to integrate the geographic information system (GIS) being developed for the Ala Kahakai National Historic Trail and initiated the framework to provide a mechanism for local steward groups to maintain and monitor sections of the trail in compliance with National Park guidelines. 



\section{Table of Contents}

Chapter 1 - Introduction ................................................................................................ 1

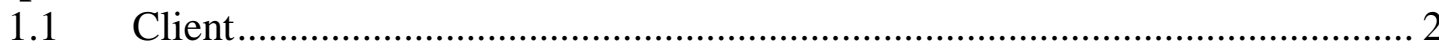

$1.2 \quad$ Problem Statement ........................................................................... 2

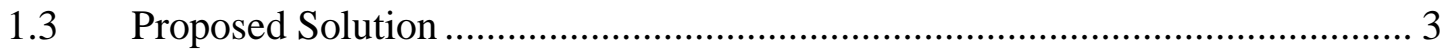

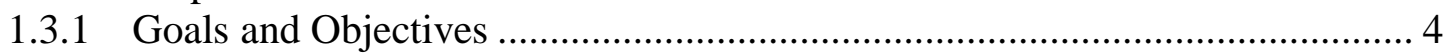

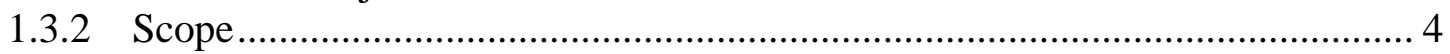

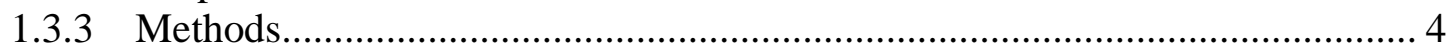

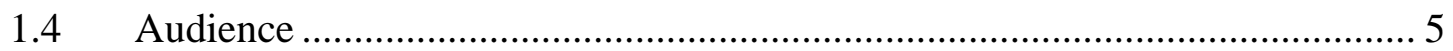

1.5 Overview of the Rest of this Report ......................................................... 5

Chapter 2 - Background and Literature Review ............................................................ 7

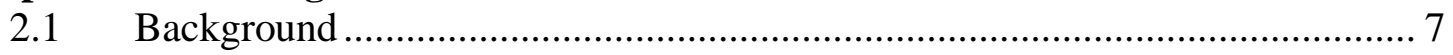

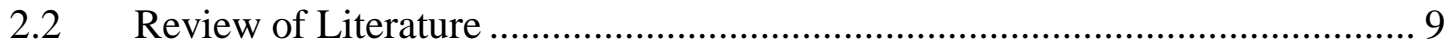

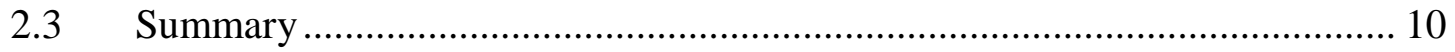

Chapter 3 - Needs Assessment and Requirements Analysis ...................................... 11

$3.1 \quad$ Project Plan .................................................................................. 12

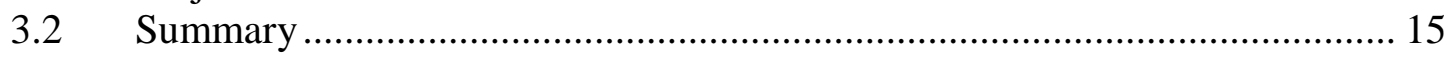

Chapter 4 - Systems Analysis and Design........................................................................... 17

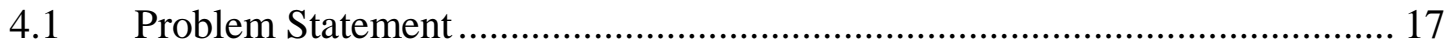

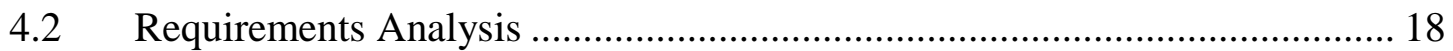

4.2.1 System Design .................................................................................... 18

4.2.2 Functional Requirements ....................................................................... 20

4.2.3 Nonfunctional Requirements .................................................................. 20

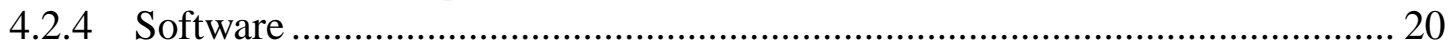

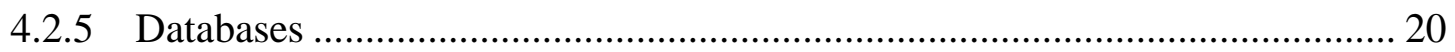

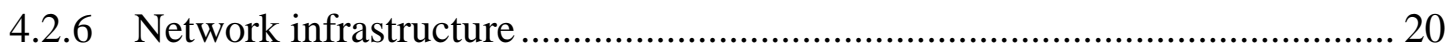

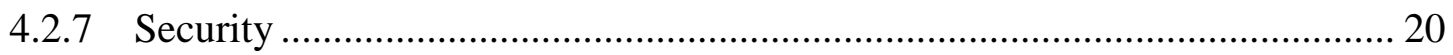

4.2.8 End-user environment .......................................................................... 20

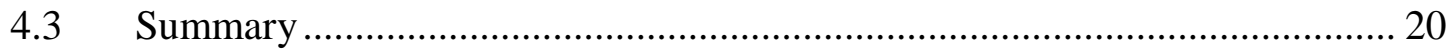

Chapter 5 - Database Design.................................................................................................. 21

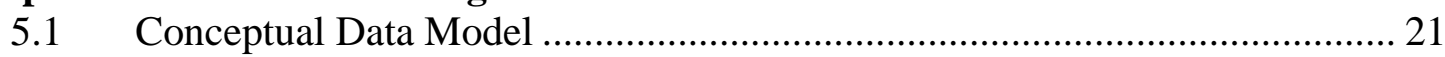

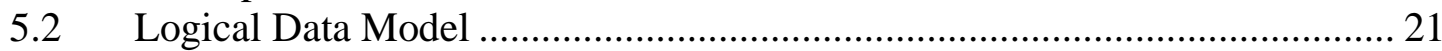

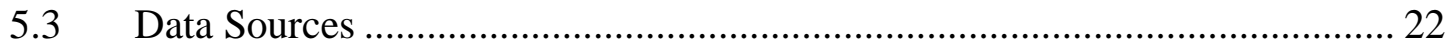

5.3.1 Minerbi Collection, UHDRP Data............................................................ 22

5.3.2 Cultural Data Collection ……………………….................................... 23

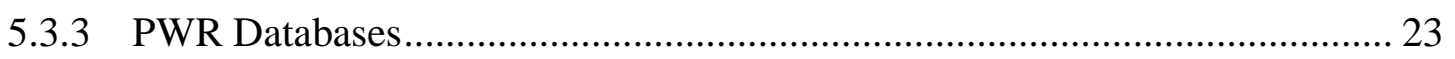

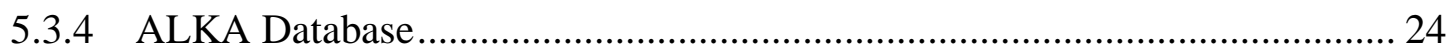

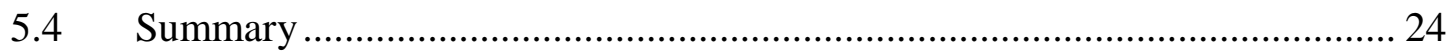

Chapter 6 - Implementation........................................................................................ 25

$6.1 \quad$ Non-spatial data inventory recommendations ............................................. 25

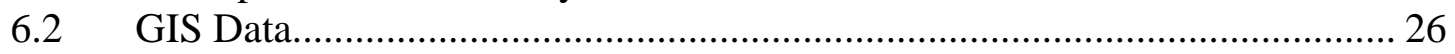

6.3 Cultural Data Collection ........................................................................... 27 


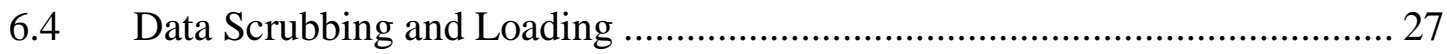

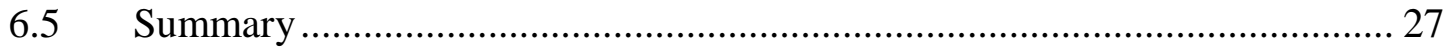

Chapter 7 - Data Management Strategy ........................................................................... 29

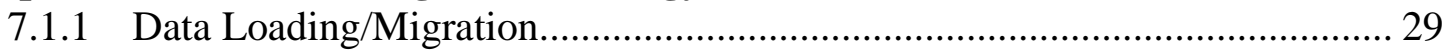

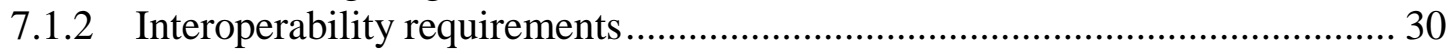

7.1.3 File Naming Conventions and Directory Structure ....................................... 30

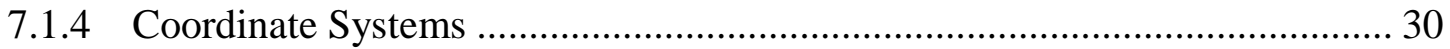

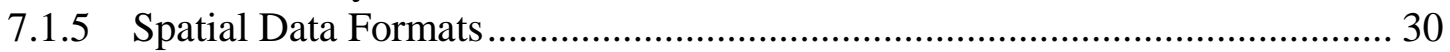

7.1.6 Security requirements …………………………................................... 30

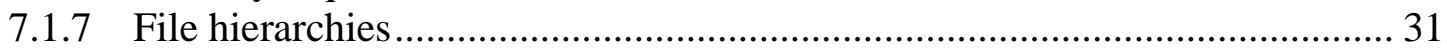

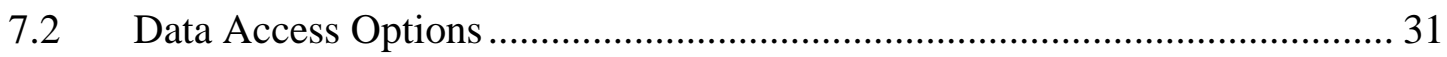

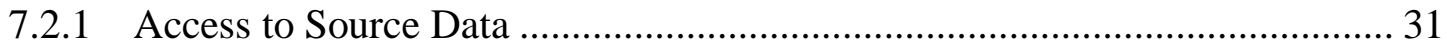

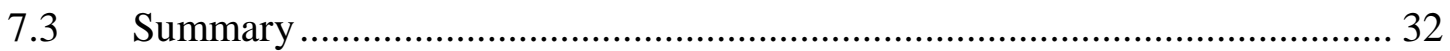

Chapter 8 - ALKA Map Templates \& Cartography .................................................. 33

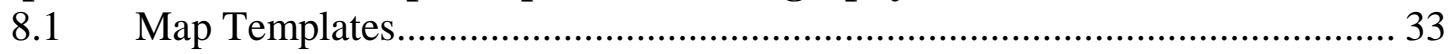

$8.2 \quad$ Cartographic Resources …………………………............................... 34

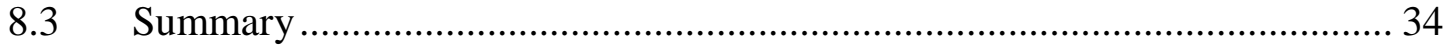

Chapter 9 - Conclusions and Future Work ….................................................... 35

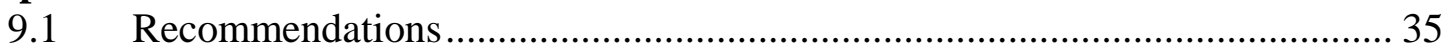

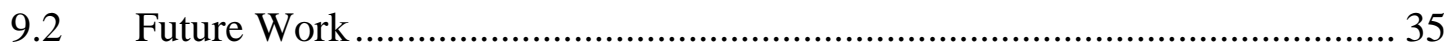

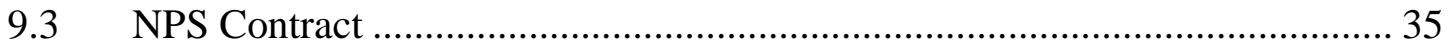

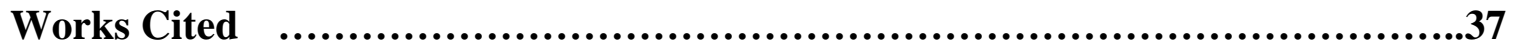

Appendix A. Needs Assessment .......................................................................................... 39

Appendix B. Geodatabase Standards ........................................................................... 41

Appendix C. Delivered Hard Drive Data Structure ......................................................... 43

Appendix D. Map Template Examples............................................................................... 45

Appendix E. Simplified Example of the Data Inventory .............................................. 47 


\section{Table of Figures}

Figure 1 - Ala Kahakai Trail, in red, on the island of Hawai'i ................................ 1 Figure 2 - Typical historic ahupua'a. Based on illustrations in A Cultural History of Three Traditional Hawaiian Sites, Greene, L. W. (1993)............................................ 3

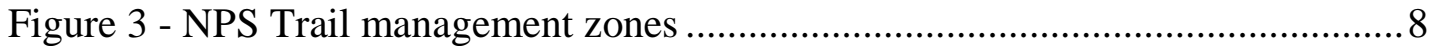

Figure 4 - Project Plan Schedule......................................................................... 14

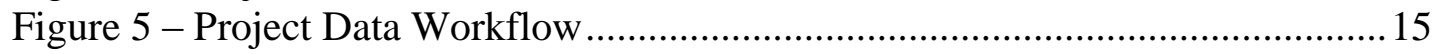

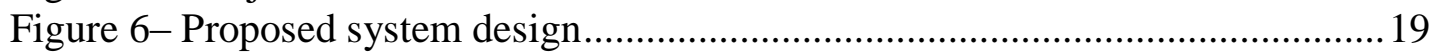

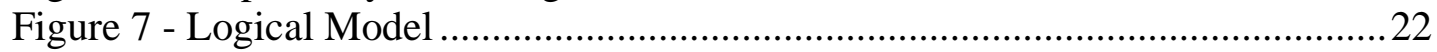

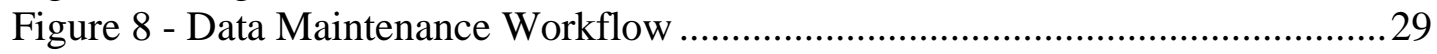

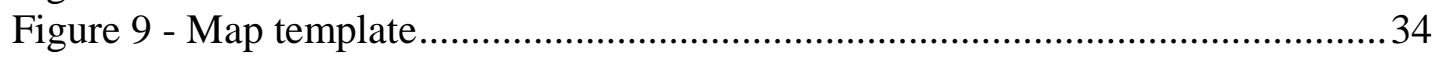

Figure D1 - 8.5 x 11 horizontal template showing the various grid systems for

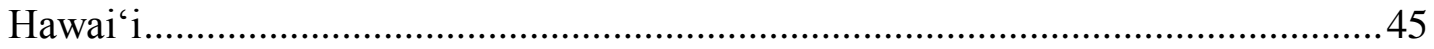

Figure D2 - 8.5 x 11 horizontal template showing male population compared to the total population at the census block group level.................................................... 45

Figure D3 - 8.5 x 11 vertical template showing the average annual maximum temperature ......................................................................................... 46

Figure D4 - 8.5 x 11 vertical template showing the density of cultural resources and

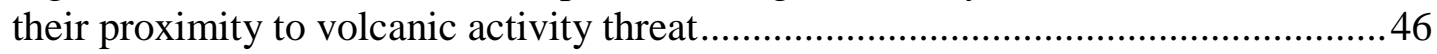

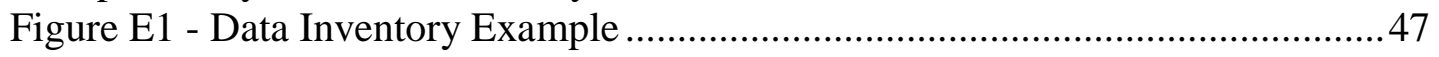





\section{List of Tables}

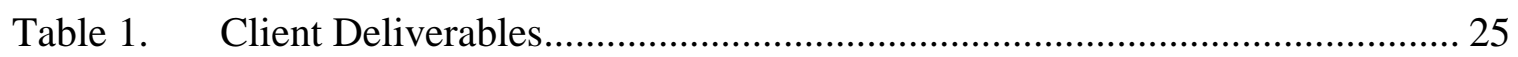

Table 2. Recommended of Non-spatial resources catalog fields ............................. 26 



\section{List of Acronyms and Definitions}

Ahupua'a - common subdivision of the land. It consists most frequently of a slice of an island that goes from the top of the local mountain (volcano) to the shore, following the banks of a stream. Ahupua'a vary in size depending on the economic means of the location and are meant to support roughly equal numbers of people.

FGDC - Federal Geographic Data Committee

GIS - Geographic Information Systems

GPS - Global Positioning System

I \& M - Inventory and Monitoring

NARA - Needs Assessment \& Requirements Analysis

NHT - National Historic Trail

NPS - National Park Service

PACN - Pacific Island Network

UHDURP - University of Hawai'i, Department of Urban and Regional Planning 



\section{Chapter 1 - Introduction}

The Kohala Center, in partnership with the National Park Service (NPS), plans to develop an ecosystem collaboratory for the Island of Hawai' $i$. The partnership will encourage the interaction between educational institutions and the local community to integrate traditional Hawaiian cultural knowledge with Western scientific data. The final product will be an "interactive, online, geospatial knowledge portal that provides scientists, educators, students, community members, and business leaders with critical information, modeling and visualization tools, and that builds appreciation for the rich and complex Island landscape" (Hamabata, 2006). The first phase of this project was to conduct a needs assessment, inventory, assess and integrate the GIS being developed for the Ala Kahakai National Historic Trail, Big Island, Hawai' $i$ (Fig. 1), organize the data into GIS databases, develop a data management strategy, and create NPS-compliant map templates to aid NPS-ALKA data management and outreach efforts. This provided the framework for local steward groups to maintain and monitor sections of the trail in compliance with National Park guidelines.

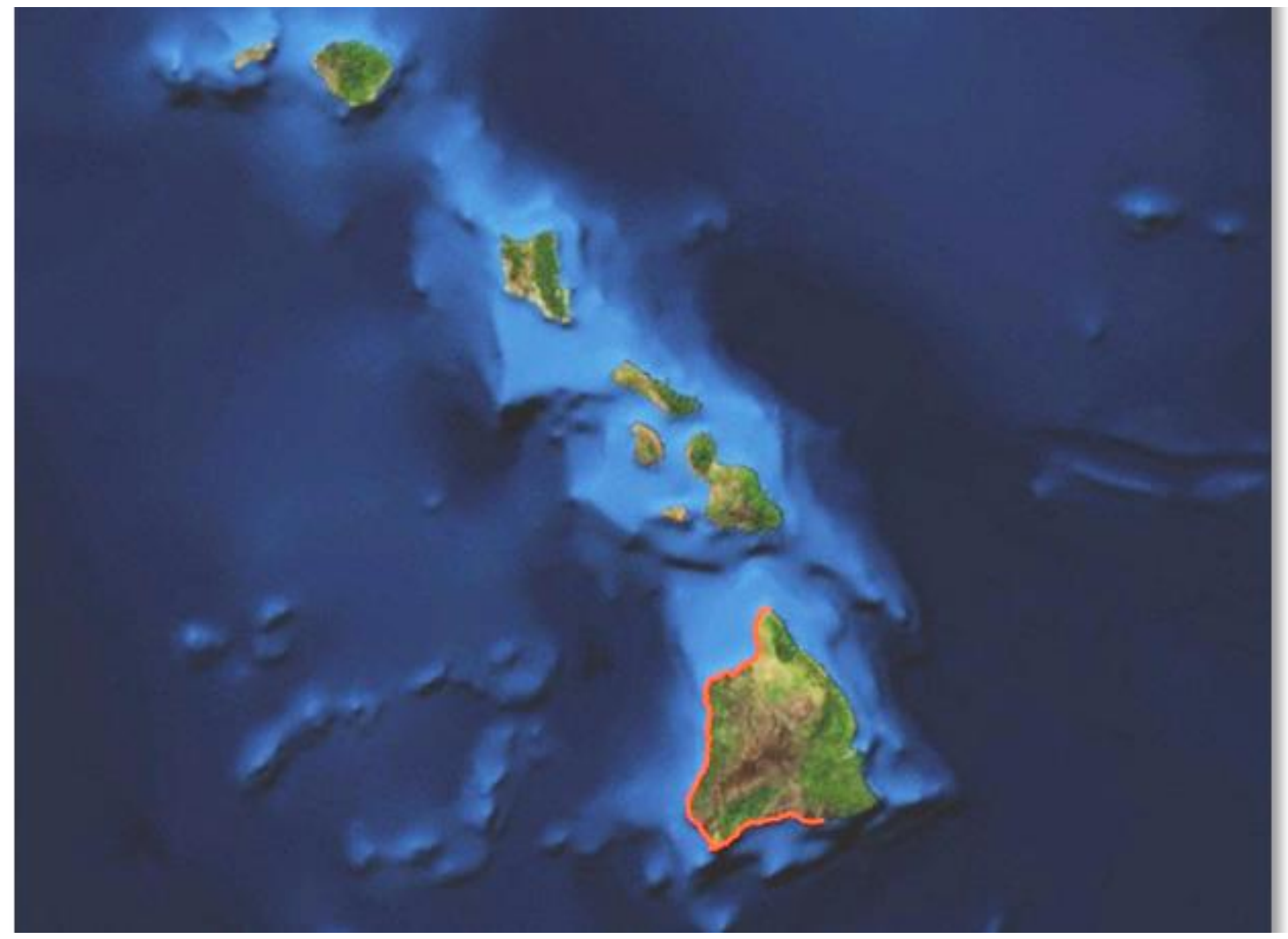

Figure 1 - Ala Kahakai Trail, in red, on the island of Hawai'i 


\subsection{Client}

Aric Arakaki, Superintendent for the Ala Kahakai National Historic Trail, provided the data currently held by the NPS and Dr. Luciano Minerbi, University of Hawai' $i$, Department of Urban and Regional Planning, and reviewed the NPS compliance standards implemented within this project.

Karen Kemp, Senior Scientist with The Kohala Center, is working on the trail stewardship program for the Ala Kahakai National Historic Trail and with the Kohala Center on a vision for an island-wide GIS infrastructure integrating Hawaiian and Western science (University of Redlands, MSGIS, 2006). For this project, Dr. Kemp acted as a consultant and liaison with the staff at the Ala Kahakai National Historic Trail and the Kohala Center, maintaining the overall vision of the island-wide system.

\subsection{Problem Statement}

Based on a user needs assessment (Appendix A) and following NPS guidelines, it was determined that the Ala Kahakai NHT needed a geospatial database, data inventory, standard map templates and a method for steward groups to monitor and maintain sections of the trail (Kemp, 2007). "The purpose and vision for the trail, crafted over many meetings and talks with community members along the route and elsewhere on the island of Hawai'i, reflect the values of a Hawaiian people who preserve and care for their land and their traditions. From this caring, cultural concepts have developed that will guide management of the trail: kuleana, responsibility; laulima, working together; malama, caring for, preserving; aloha 'aina, love of the land, among others." (Ala Kahakai National Historic Trail Comprehensive Management Plan, NPS, 2009).

The Ala Kahakai NHT, which is divided into six management areas and bisected by over 200 traditional Hawaiian division of land ahupua'a, crosses four national parks as well as much private land. (Fig. 2) Staff members at The Ala Kahakai NHT have experienced a number of challenges when trying to engage local community groups for stewardship of the trail segments that cross these privately held lands. 


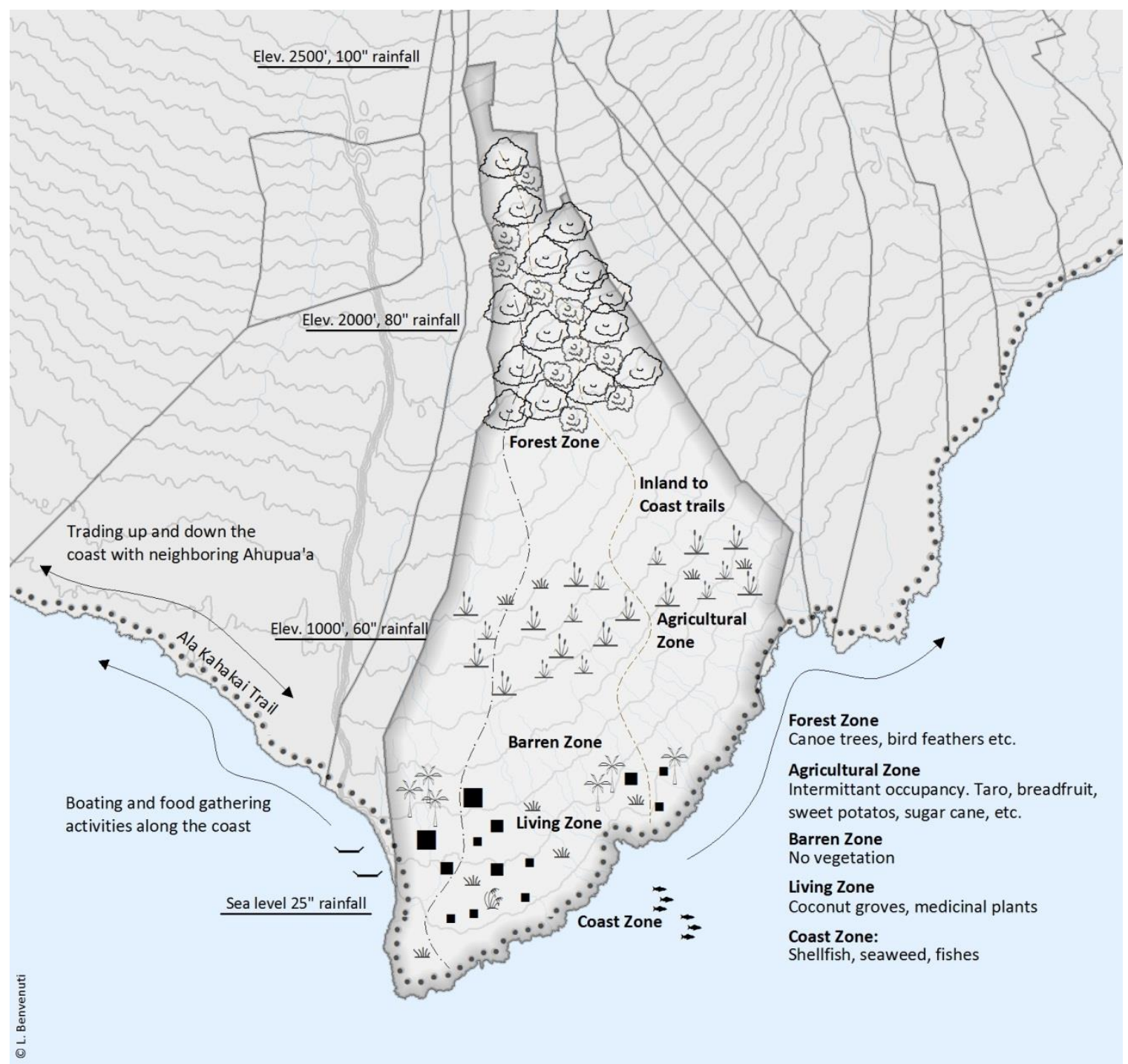

Figure 2 - Typical historic ahupua'a. Based on illustrations in A Cultural History of Three Traditional Hawaiian Sites, Greene, L. W. (1993).

\subsection{Proposed Solution}

This project integrated previous work on behalf of the Ala Kahakai NHT staff to further develop a geospatial database by completing an inventory and assessment of current data, identified data gaps, and created NPS-compliant map templates (Appendix E) to aid NPS-ALKA data management and outreach efforts.

An ArcGIS personal geodatabase was structured to follow NPS standards and guidelines. This will enable Ala Kahakai NHT staff to preserve and manage sections of the trail within the four National Park boundaries, and to work with steward groups to manage individual sections. A number of ArcMap templates were developed to allow 
staff to quickly evaluate the status of trail sections and to convey this information graphically in reports and public outreach efforts.

\subsubsection{Goals and Objectives}

The goal of this project was to provide the Ala Kahakai NHT staff with an organized database, data standards, maps templates, and a methodology to continue to comply with the goals of the Ala Kahakai National Historic Trail Comprehensive Management Plan: to preserve the cultural resources associated with the trail, to enable public access to the trail, and to contribute to the sustainability of natural resources along with the trail.

\subsubsection{Scope}

During the needs assessment \& requirements analysis (NARA) it was determined that the Ala Kahakai NHT staff needed an organized set of data to meet the goals of the Ala Kahakai National Historic Trail Comprehensive Management Plan. To accomplish this, the data first needed to be inventoried and assessed for its value to the project area, metadata had to be reviewed and in many cases written, and a data management and maintenance strategy need to be developed to ensure continued operation and protection of the trail.

\subsubsection{Methods}

The first step of this project was to engage Ala Kahakai NHT staff and other stakeholders in a NARA to identify specific needs, restrictions, and constraints. A systems assessment was administered to evaluate existing GIS software capabilities of the Ala Kahakai NHT and expected user groups. Existing non-restricted GIS data and all corresponding documentation were provided by both primary clients. All NPS standards were maintained within the scope of the project.

Key map and data layers were identified by the clients to be used in agency reports, outreach efforts and restoration and conservation of the historic trail. Online data sources were accessed for baseline statewide and county data and organized. A naming convention was applied indicating if it was statewide data ('HI_....') or if it was county wide data ('Hawaii_....'). Data assessment was performed to evaluate data quality for each existing dataset (includes source and appropriate use scale, interoperability, topological constraints and completeness, attribute completeness) and determine the suitability of in house data and data gaps. The trail footprint was integrated with the ahupua'a boundaries to identify steward groups. The metadata was reviewed for FGDC \& NPS compliance and updated where possible.

A collection of aerial photos, scanned maps, map footprints, reports and trail maps was provided by Dr. Minerbi (UH). Cultural data were acquired from the State Historic Preservation Division of the Department of Land and Natural Resources. An assessment of these data sources was performed and provided to the client. Duplicate records and multiple errors were found in the cultural records and there was an attempt to check, clean, and resolve these issues where possible. Most were identified in the report to be passed on to the state agency for resolution. The Minerbi collection was retained and used as delivered. A data inventory was provided to the client as an Excel spreadsheet. 
A data management strategy and workflow (Appendix B) were documented including topological, tolerance, projection and metadata standards. (Appendix C). A systems assessment was performed to evaluate existing GIS software capabilities and provide recommendations with NPS IT limitations. NPS compliant map templates and standard map symbology and ArcMap styles were developed for the client to facilitate consistent and easy visualization.

\subsection{Audience}

Although the data, management strategy and data and metadata standards are intended to be used by the Ala Kahakai NHT staff, the underlying principles can be understood and used by GIS project data managers at a more general level.

\subsection{Overview of the Rest of this Report}

Chapter 2, Background and Literature Review, provides the geographical description and cultural significance of the Ala Kahakai National Historic Trail. Chapter 3, Needs Assessment and Requirements Analysis, outlines the results of interviews conducted by Karen Kemp in 2008 of park staff on the issues, opportunities, constraints and priorities, as well as outlining project outputs. Chapter 4, Systems Analysis, describes the functional requirements, hardware and software recommended. Chapter 5, Database Design, defines the conceptual and logical data models as well as data sources and data processing performed. Chapter 6, Implementation, discusses not so much an implementation of any application but the data and document deliverables that will allow the Ala Kahakai NHT staff to meet management goals. Chapter 7, Results and Analysis, describes the final report delivered to the client. Chapter 8, Future Data Management Strategy, outlines a standardized data management process, data access options, map services, catalog/metadata services and applications, map templates and cartographic resources. Chapter 9, Conclusions and Future Work, recommends the development of tools and workflows to help in daily use of GIS by staff for routine management and to help staff engage local community and agencies. Also discussed is the Redlands Institute contract to develop a Knowledge Management System, a Land Development Process Tracking Tool, and a Trail Planning and Management Tool. 



\section{Chapter 2 - Background and Literature Review}

This chapter discusses the physical and cultural aspects of the trail as well as NPS efforts at conservation and management. The literature review lists several island wide efforts to collect and share information, integrate science, and preserve cultural resources.

\subsection{Background}

The Ala Kahakai National Historic Trail, Big Island, Hawai 'i, was established in 2000 to preserve and protect traditional Native Hawaiian culture and natural resources. The 175mile trail contains many sites of cultural and historical significance. It travels through hundreds of historic settlement sites and through over 200 ahupua'a, or traditional sea to mountain land divisions. Cultural resources along the trail include several important heiau (temples), royal centers, kahua (house site foundations), loko 'ia (fishponds) ko`a (fishing shrines), ki`i pohaku (petroglyphs), holua (stone slide), and wahi pana (sacred places). Natural resources along the trail include ponds, reefs, estuarine environments, coastal vegetation, migratory birds and sea turtle habitat, and several threatened and endangered native species of plants and animals (National Park Service, U.S. Department of the Interior, 2007).

Although the 175-mile long Ala Kahakai trail joins all four national parks, it is not a single continuous trail. "The term 'ala kahakai' (trail by the sea) is a modern term developed by hiking advocates in the 1970's who were promoting the idea of a 40-mile hiking trail along the coast from Kawaihae to Kailua-Kona." The Ala Kahakai is a collection of historic coastal trails that were once part of a network of trails that crossed the island (Mauna Kea Visitor Information Station, 2006).

The Ala Kahakai NHT was determined to be significant because it contains the oldest example of the Ala Loa, the major land route connecting the coastal reaches of most ahupua'a and includes remnants of several other historic shoreline trails. The trail played an influential role in Hawaiian history and is associated with numerous historic and pre-historic events, royal centers, housing areas, resource gathering, regional trade, temples, and natural resource areas and has been continuously used since the leeward and southern coasts of the island were inhabited by native Hawaiians and continues to be used as an access way today for inter- and intra-ahupua'a travel (Ala Kahakai National Historic Trail Planning Team, 2004).

The trail is divided into six management zones (Fig. 3) following traditional boundary lines. Each zone has a different management prescription for trail condition and facilities based on the sacredness of the area, the physical characteristics, and the community group involved. The four sections of the park which run through NPS land are administered and maintained by the NPS. There are plans in place for all other sections to be maintained through a Trail Stewardship Program. Steward groups will be determined by the ahupua'a and will follow the management guidelines in the NPS Inventory \& Monitoring Program (Kemp, 2007). 


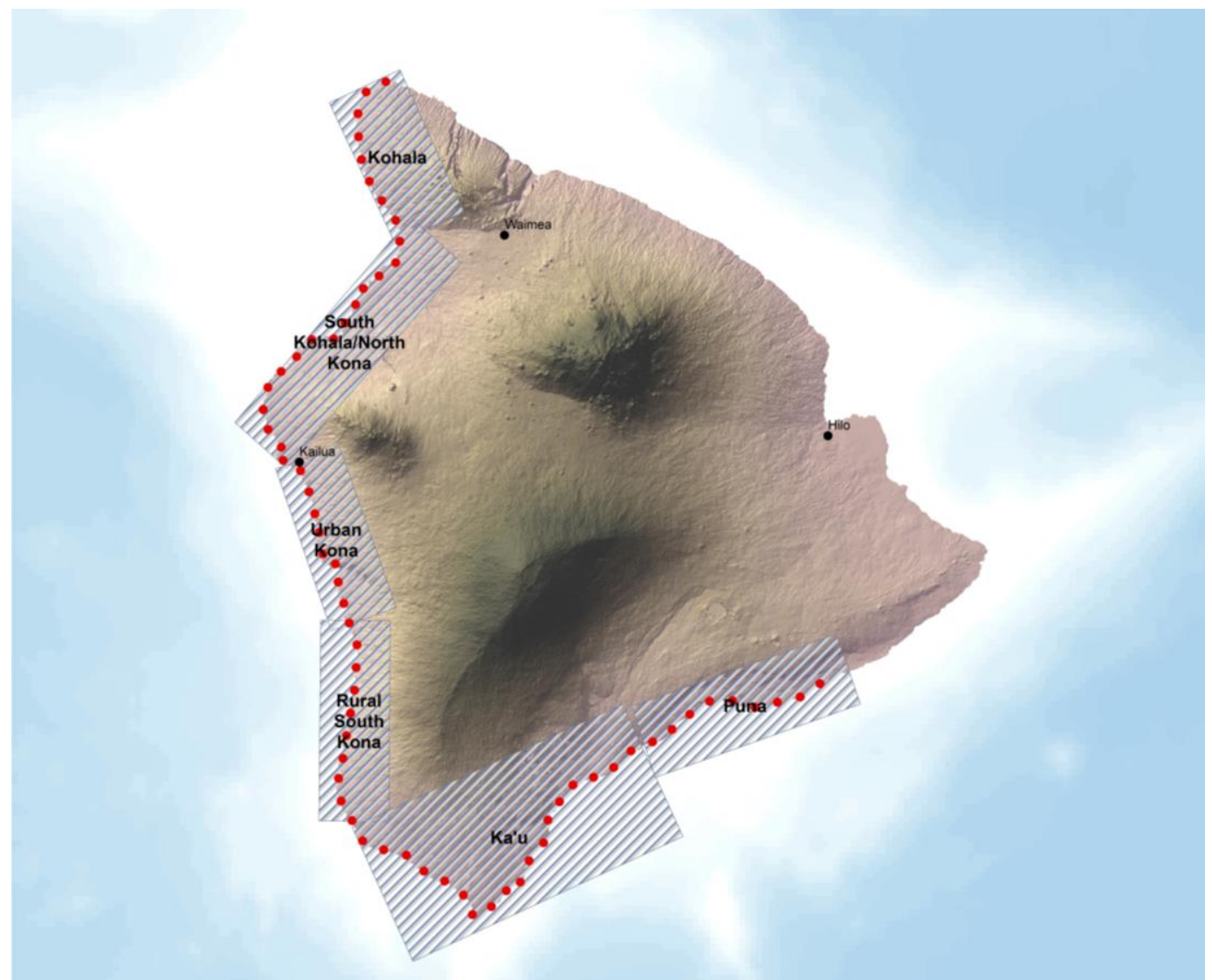

Figure 3 - NPS Trail management zones

The NPS Data Management Plan for the Pacific Island Network (PACN) is a guide for managers and staff to ensure the quality and documentation of data management methods and procedures. The Data Management Plan references other documents which specify the standards and steps for achieving the PACN's goals.

The overall goal of the NPS Inventory \& Monitoring (I\&M) Program is to provide scientifically sound data to support the decisions made for the protection of park resources. The program's data management mission "is to ensure the quality, interpretability, security, longevity and availability of program natural resource data." (Dicus, G. H. 2006).

The goals of the PACN I\&M Program are to:

- Ensure the high quality and long-term availability of the data and analyses

- Integrate data activities with all other PACN business

- Specify data stewardship responsibilities

- Work to improve the quality and availability of NPS data from outside sources

The PACN's Data Management Plan and I\&M Program have sections devoted to standards and procedures related to data management priorities, stewardship roles and responsibilities, data and information workflows, infrastructure and system architecture, database design strategies, data quality, data documentation, data analysis and reporting, 
data dissemination, digital data maintenance, storage, and archiving, and access to sensitive data.

\subsection{Review of Literature}

Modern mapping of indigenous lands started in the 1960s. Projects to secure occupancy, manage natural resources, and strengthen cultures began in Canada and have now spread around the world, ranging from sketch maps to full GIS implementation (Chapin, Lamb, $\&$ Threlked, 2005). Indigenous knowledge systems are being impacted by rapid changes in technology and social environments. Participation of local communities in resource management helps ensure that their needs are met, while at the same time preserving the local skills, artifacts, and problem solving strategies (Tripathi \& Bhattarya, 2004). Emerging technology can also rekindle interest in young people of cultural beliefs and landscape knowledge (Aporta \& Higgs, 2005).

Indigenous knowledge, i.e. 'traditional knowledge' or 'community knowledge' is that which has grown within the community and has been passed down through generations in order to preserve and honor the knowledge of their ancestors (Tripathi \& Bhattarya, 2004). The ability to collect, record, and communicate this knowledge was and is essential to a people's physical and spiritual well-being, as well as their survival and stewardship of the land. Methods have changed through time and are facing a new change with GIS (Chambers, K., et al, 2004).

Knowledge management systems focus on the collection of knowledge to be used for decision making. It is in the participatory process that the people involved are able to share and leverage information among scientists and communities (Tripathi \& Bhattarya, 2004). There is a fulfillment people get from the interaction of who they are and where they are (Aporta \& Higgs, 2005). On one hand, current technology such as GIS and GPS threaten the historical methods of indigenous people of passing knowledge from one generation to another through story-telling, art, and other traditional methods. Although it may have its limitations, it can be used to preserve and promote natural resource management that incorporates both western scientific principals and indigenous knowledge. Successful and sustainable management of natural resources can only be achieved by developing a science based on the priorities of local people and creating a technological base that includes both traditional and modern approaches to problem solving (Tripathi \& Bhattarya, 2004).

Most community applications of GIS have been for natural resource management, land use rights, and property status. The spatial nature of traditional knowledge lends itself to GIS as has been explored by American Indians, as well as in the Philippines and New Zealand. When indigenous people develop and use GIS, they are able to imprint their own culture on these applications (Tripathi \& Bhattarya, 2004). GIS software can provide indigenous people with technological tools that empower them by creating maps in their own language, maps crammed with place names that fill the blank spaces and make an area appear less desirable for development, and maps sensitive to their own culture and spiritual traditions (Louis, 2004). In past efforts, the staff at the Ala Kahakai NHT has encountered some resistance from the local community. Increased access to the trail by visitors may endanger what they consider sacred cultural and archeological sites. The NHT is aware of this and hopes that community involvement will alleviate these concerns (Kemp, 2007). In 1998, the National Park Service established a framework for 
an Inventory and Monitoring (I\&M) Program. The Data Management Plan for the Pacific Island Network has strong GIS components, including data documentation, data analysis and reporting, and data dissemination (Dicus, 2006). GIS is also incorporated into the National Trails System Memorandum of Understanding between six federal agencies whose purposes are as follows:

- Administration of National Trails

- Management of Trail Sites and Segments

- Cooperation and Partnerships

- Recreational Opportunities and Visitor Satisfaction

- Enhancement of Cultural Values

- Funding (National Park Service, U.S. Department of the Interior, 2006a)

The National Park Service considers the preservation of cultural resources a top priority. The Pacific Island Network Vital Signs Monitoring Plan states that all records of natural and cultural resources and their management are considered mission-critical and GIS will be used for data stewardship and management (HaySmith, 2005).

\subsection{Summary}

The goals of the Ala Kahakai National Historic Trail Comprehensive Management Plan are to preserve the cultural resources associated with the trail, enable public access to the trail, and to contribute to the sustainability of natural resources along with the trail. An ArcGIS personal geodatabase structured to follow NPS standards and guidelines will enable Ala Kahakai NHT staff to preserve and manage sections of the trail within the four national park boundaries and to work with multiple steward groups with various technological capabilities to manage their individual sections. Various ArcMap templates will allow staff to quickly evaluate the status of trail sections to convey this graphically in reports and public outreach efforts, and be used for community engagement for trail preservation by working with various educational institutions and local families. 


\section{Chapter 3 - Needs Assessment and Requirements Analysis}

The mission goals of the Ala Kahakai National Historic Trail Comprehensive Management Plan are to "restore, interpret and perpetuate the culture of native Hawaiian," preserve the cultural resources associated with the trail, enable public access to the trail, and to contribute to the sustainability of natural resources accessed by the trail (Ala Kahakai National Historic Trail Planning Team, 2004).

The Ala Kahakai NHT, divided into six management areas and bisected by over 200 ahupua'a, crosses four national parks as well as a large amount of private land. The Ala Kahakai NHT has experienced a number of challenges when trying to engage the local community groups for stewardship of the segments that cross these privately held lands. The Ala Kahakai NHT needs a geospatial database, data inventory, standard map templates, and a method for steward groups to monitor and maintain sections of the trail. Trail attributes to be managed include: access points, signs, restroom facilities, cultural interpretation, conservation and ecological management strategies (Kemp, 2007).

Current skill sets for data compilation, integration, and quality control are sufficient for this project. Additional web development skills are not determined at this time. It is assumed at this time that hardware and software requirements are adequate.

Both Aric Arakaki, Superintendent for the Ala Kahakai National Historic Trail, and Karen Kemp, consultant and liaison with the staff at the Ala Kahakai National Historic Trail, were very involved in this project. Both participated in the needs assessment and requirements analysis, which defined the data and applications needed. Mr. Arakaki provided the data currently held by the NPS and the University of Hawai' $i$, Department of Urban and Regional Planning (UHDURP), and reviewed NPS compliance standards implemented within this project. He and Dr. Kemp collected the necessary data and Dr. Kemp transferred that data. She was also available for consultation during the course of this project.

The NARA report identified issues, opportunities, constraints and priorities, as well as outlining project outputs:

- Overview of the past, present and planned stakeholder activities, data, computer resources, and staff technical capacity

- Overview of the functions and processes

- Evaluated existing hardware and GIS software capabilities as a basis for the development of subsequent documents, particularly the conceptual application and database design, and implementation plan.

- Identified end user options, such as a public website with data discovery and access tools

The GIS User Needs Report identified the following Ala Kahakai National Historic Trail Business Processes:

- Planning for trail administration, development and management - make informed and timely decisions regarding trail alignment, evaluate compliance to regulations and permits of shoreline developments; locate historic trail segments protected or not protected under the Highways Act, determine location of cultural and natural 
features that will be affected by use of the trail, and determine owners so they can be engaged in the planning process.

- Land use planning - development of environmental and cultural impact statements, engage public in the development of statements and plans.

- Trail planning - includes landscape planning, precise trail alignment on the ground, slopes, location of parking, access, toilets, and other amenities, identification and management of safety issues.

- NPS trail management, inventory, and monitoring (I\&M) activities - inventory of cultural and natural resources, monitoring impacts of trail use and access on cultural and natural resources, planning for management activities such as herbicide use, managing trail segment closures, and determining trail carrying capacity (both environmental and spiritual).

- Public Outreach - general public education, orientation of where things are, provision of information about trail access, features, hazards, and safety.

- Support trail segment management entities (TSMEs, or segment managers) share knowledge and learn more about their land, give access to information they didn't have previously, assist them to report trail corridor problems and issues, support their I\&M activities (need both digital and hard copy).

Deliverables (Appendix D) included NPS compliant data and metadata, a data inventory report, data maintenance and cataloging strategy for both spatial and nonspatial data, and various map template designs and cartographic resources. Ala Kahakai NHT staff hopes that these and other applications will be used for community engagement for trail preservation by working with various educational institutions and local families.

\subsection{Project Plan}

The project plan was followed very closely with Dr. Karen Kemp conducting the User Needs Assessment on site in Hawaii. The project was completed through five major phases:

1. User Needs Assessment \& Requirements Analysis (NARA)

The NARA report identified issues, opportunities, constraints and priorities as well as outline project outputs. The stakeholder interviews documented past, present and planned activities. The Requirements Analysis reviewed planned functions and processes and evaluated existing hardware and GIS software capabilities.

\section{Data Organization Structure}

This task documented all standards for data deliverables. It identified and prioritized key map and data layers, developed naming conventions compliant with NPS standards, documented topological, tolerance, domain, subtype, and relationship rules, and outlined a geodatabase design.

\section{Data Assessment \& Analysis}


The data assessment and analysis task evaluated the current data, updated data where needed, assessed and updated metadata, and performed data integration and analysis. Each dataset was evaluated for quality, including the source and appropriate use scale, interoperability, topological constraints and completeness, and attribute completeness. Public state and county held data was obtained and migrated into a common database. Analysis and integration with the trail footprint and ahupua'a boundaries was performed. Database QA/QC identified data gaps and a Data Inventory Report (Appendix F) which defined title, source, scale, date, restrictions, etc. was delivered.

\section{Map Template design}

Using existing NPS fonts and graphics, ArcMap map templates were developed to allow staff to quickly evaluate the status of trail sections and to graphically convey this information in reports and public outreach efforts.

\section{Implementation and Maintenance Recommendations}

Recommendations were provided to staff for maintaining and documenting both GIS and non GIS data on using GIS for routine park management, community involvement, and public outreach. 
Project Plan Schedule for the Development of a Geospatial Database for Ala Kahakai National Historic Trail, Big Island, Hawai'I Lisa Benvenuti, UoR MS GIS Cohort 11.5

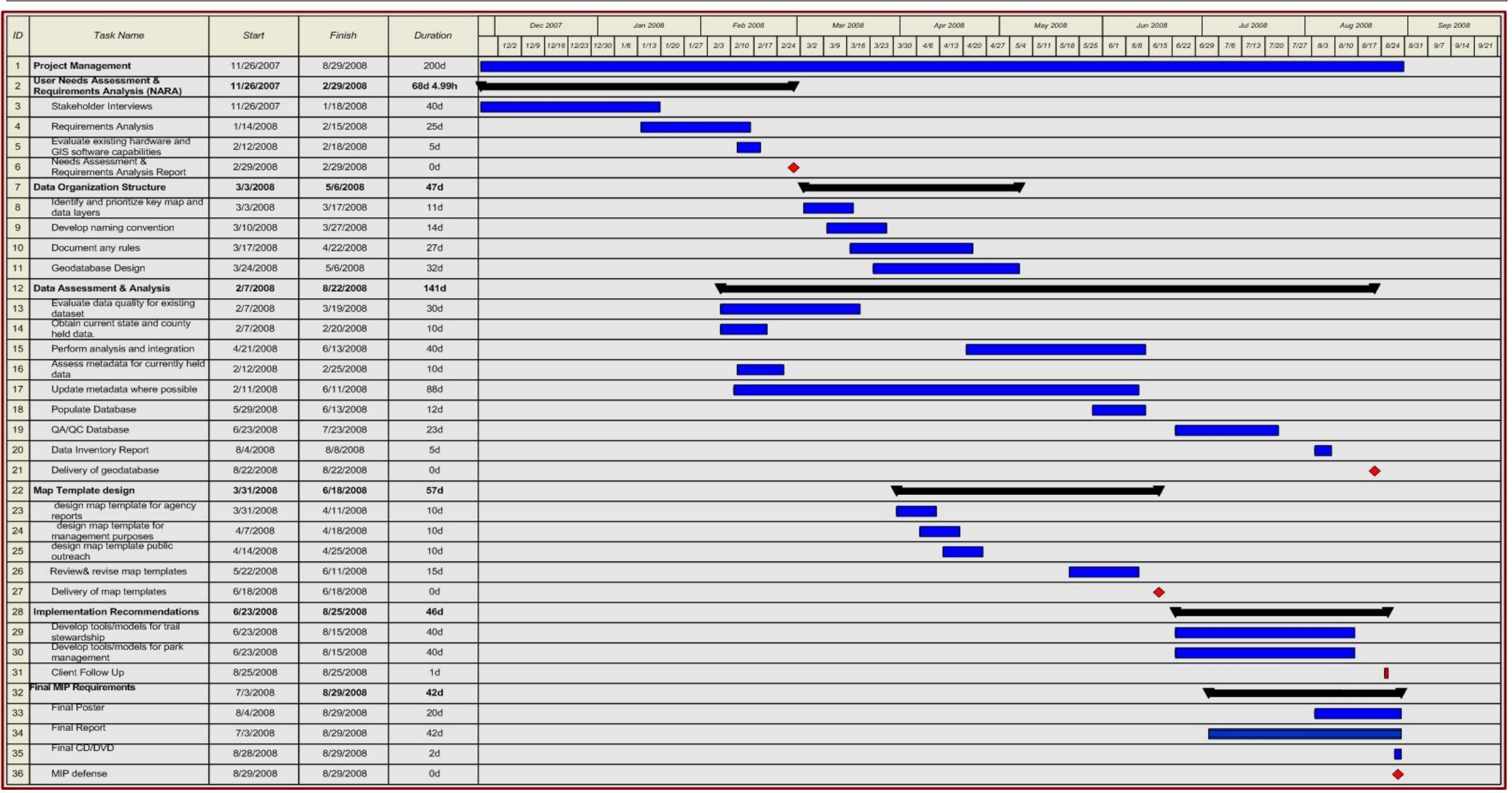

\section{Figure 4 - Project Plan Schedule}




\subsection{Summary}

Ala Kahakai NHT staff required an organized database, data standards, maps templates, and a methodology to continue to comply with the goals of the Ala Kahakai National Historic Trail Comprehensive Management Plan. All data processing and documents were delivered as planned and on time (Fig. 5) with the exception of the cultural resource data provided by the State Historic Preservation Division of the Department of Land and Natural Resources. This data proved to contain too many errors to be considered of much value. A report on this was provided to the client.

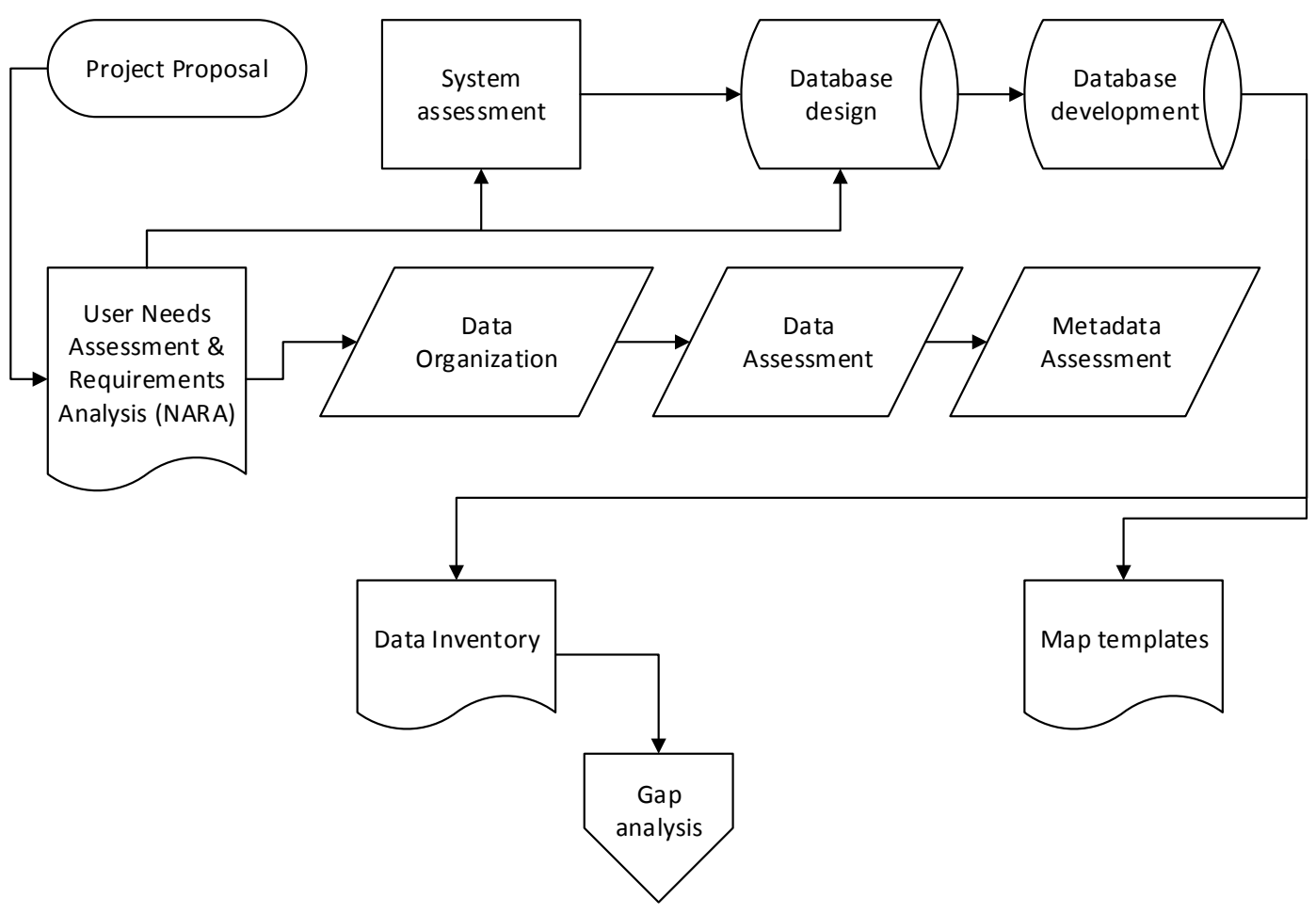

Figure 5 - Project Data Workflow 



\section{Chapter 4 - Systems Analysis and Design}

National trail comprehensive management plans are intended to be long-term documents that articulate a vision for the future of the trail, including the management philosophy and the framework to be used for decision-making and problem solving. This comprehensive management plan (CMP) will provide guidance for approximately the next 15 years. The purpose of this CMP is to establish the administrative objectives, policies, processes, and management guidelines needed to fulfill the preservation and public use goals for the Ala Kahakai National Historic Trail (NHT) in accordance with the National Trails System Act (16 USC 1244, § 5(f)). (NPS, 2009)

The preferred alternative (Alternative C: Ahupua'a Trail System) of the Ala Kahakai National Historic Trail Draft Comprehensive Management Plan \& Environmental Impact Statement is based on the traditional Hawaiian trail system in which multiple trail alignments within the ahupua'a are integral to land use and stewardship. The linear trail would be protected, as in alternative B ("Single Trail, considered completion of a single continuous trail comprised of unaltered or verified ancient and historic portions of the ala loa (coastal trail around the island) linked as needed by later pre-1892 trails, pathways, and modern connector trails. Within the planning period of 15 years, the goal would be to complete the linear trail within the priority zone from Kawaihae to Ho'okena and to protect other segments along the route outside of that area as feasible. The actions and strategies described above would be applied to the single linear trail. In the long-term, cultural and natural resources along the entire trail tread and agreed upon adjacent areas would be protected and interpreted to the public. The NPS would administer the trail, but management outside of the national parks would remain with the land managing agency or landowner), but on publicly-owned lands the Ala Kahakai NHT would include inland portions of the ala loa or other historic trails that run lateral to the shoreline and would be connected to ancient or historic mauka-makai (mountain to sea) trails that would have traditionally been part of the ahupua'a system. As with alternative $\mathrm{B}$, during the 15-year planning period, the priority zone from Kawaihae to $\mathrm{Pu}$ 'uhonua $\mathrm{o}$ Hönaunau National Park would be the focus of administration and management, while sections outside of that zone would protected as feasible. Through an agreement, the state of Hawai'i could convey to the NPS a less-than-fee management interest in trail segments that are state-owned under the Highways Act of 1892 within the Ala Kahakai NHT corridor. The NPS would then be responsible for managing these segments and federal law would fully apply. However, in cooperation with the NPS, local communities of the ahupua'a would be encouraged to take responsibility for trail management using the traditional Hawaiian principles of land management and stewardship. The Ala Kahakai Trail Association would be expected to be robust enough to play a major part in trail management, promotion, and funding. (U.S. Department of the Interior, 2007).

\subsection{Problem Statement}

The goal of this project was to provide the Ala Kahakai NHT staff with an organized database, data standards, maps templates, and a methodology to continue to comply with the goals of the Ala Kahakai National Historic Trail Comprehensive Management Plan. 


\subsection{Requirements Analysis}

The priority need of the Ala Kahakai National Historic Trail staff was to have an organized, stable, quality database from which they could produce maps for various reports and outreach efforts and conduct some spatial analysis to assist with their management of trail resources. The data for Hawai' $i$ came from various sources and was found in several different projections, Old Hawaiian, and UTM Zone 4 \& 5. Since the majority of the data come from state sources, UTM Zone 4 NAD 83 was used. The requirements analysis identified a system designed to meet their GIS needs.

\subsubsection{System Design}

The GIS solutions included an ArcGIS personal geodatabase structured to follow NPS standards and guidelines which enabled Ala Kahakai NHT staff to preserve and manage sections of the trail within the four National Park boundaries, and to work with multiple steward groups of various technological capabilities to manage individual sections. A number of ArcMap templates were developed to allow staff to quickly evaluate the status of trail sections and to graphically convey this information in reports and public outreach efforts.

User requirements include the ability to produce digital map exports in .jpg and .pdf format and hardcopy maps in 8.5x11 \& 36x48 sizes, both landscape and portrait. Metadata needs to be NPS \& FGDC compliant using the NPS Metadata Tools and Editor available at http://science.nature.nps.gov/NRGIS/applications/metadata/Default.aspx.

The proposed system design (Fig 6) diagrams the ideal system for Ala Kahakai NHT staff to collect and manage data to aid them in analysis and outreach efforts and to provide the framework for local steward groups to maintain and monitor sections of the trail. The current system consists of several workstations which serve as the application and database servers and run ArcGIS software and allows them to collect data and do the maps and analysis to meet NPS management goals. Current NPS security protocols do not allow them to set up webservers to collect or share data through a data portal with steward groups. 


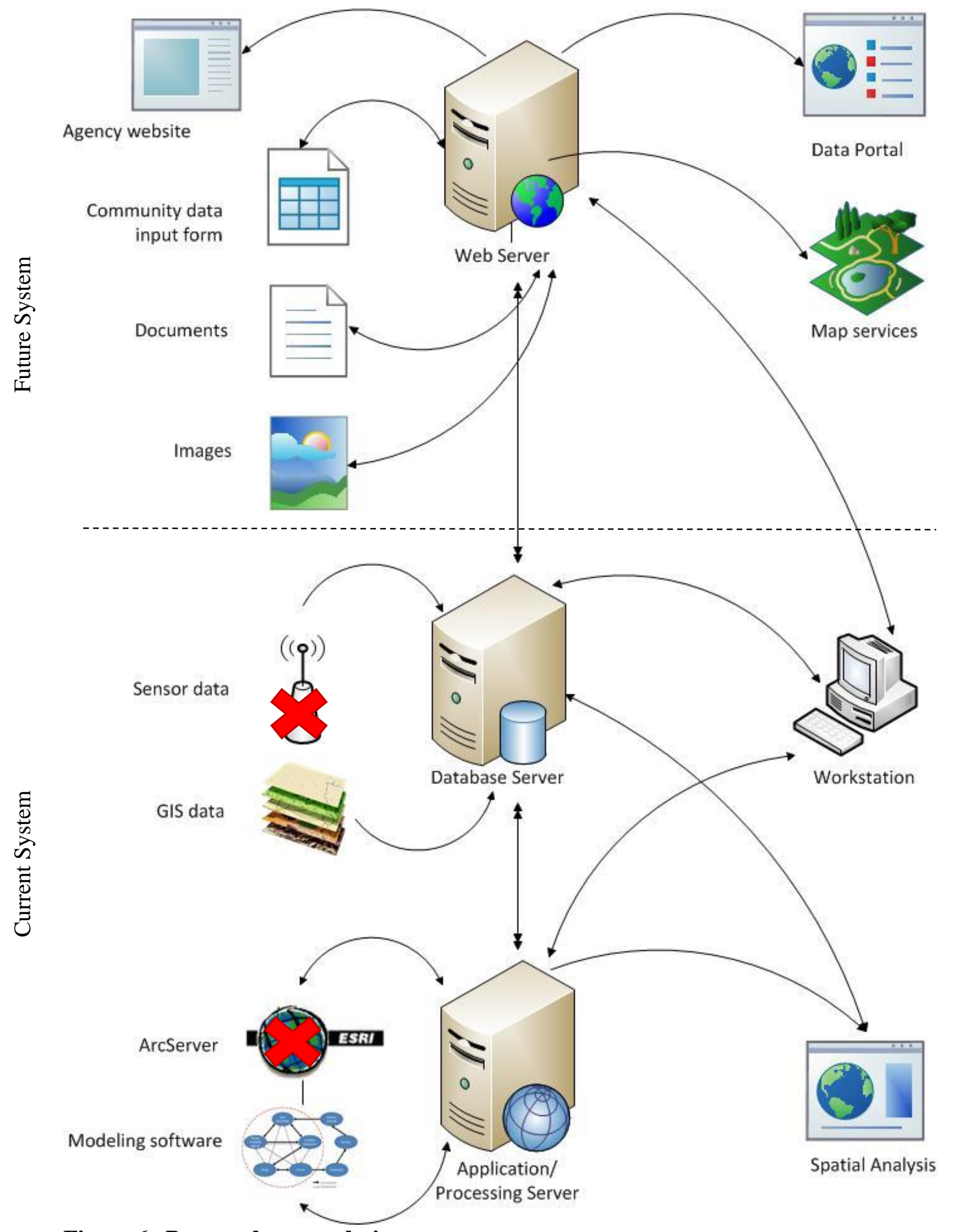

Figure 6- Proposed system design 


\subsubsection{Functional Requirements}

1. The system will be able to create geodatabases, manage geodatabase tables, add, remove, and calculate fields, create geodatabase topology

2. The system shall support the ability to be able to create \& edit data, allow for versioning, workflow process $\&$ validation rules.

3. The system will accommodate hard copy and digital map out puts for NPS reports, community outreach, education, and trail planning and management.

\subsubsection{Nonfunctional Requirements}

1. The system will be available to multiple users connected to the network

2. The systems will not be available to users outside the network

3. The system will have sufficient storage for all vector and raster data

4. The system will have sufficient processing capabilities for core functionality

\subsubsection{Software}

ESRI Arc Info Desktop 9.3 (or later) suite plus the Spatial Analyst extension.

\subsubsection{Databases}

Spatial data to be stored in an ArcGIS 9.3 (or later) personal geodatabase. Non-GIS data to be stored in its native source and converted to ArcGIS 9.3 (or later) compatible format (i.e. Excel or Access)

\subsubsection{Network infrastructure}

All office computers have networking capability.

\subsubsection{Security}

All office computers be secure from outside access.

\subsubsection{End-user environment}

No additional software requirements other than that which is included in and Arc Info level of ArcGIS 9.3 (or later) (ArcMap, ArcCatalog). To meet NPS metadata standards, the NPS Metadata Tools and Editor: Version 1.1 is required.

(http://science.nature.nps.gov/nrdata/tools/)

\subsection{Summary}

The client required an organized database, data standards, maps templates, and a methodology to maintain and use their data. The deliverables included the data and cartographic resources for them to meet their management goals as well as maintenance recommendations. 


\section{Chapter 5 - Database Design}

Agency specific spatial data and non GIS datasets were organized and retained in their native source format. A collection of publicly available federal, state and county datasets was compiled into an ArcGIS 9.3 personal database.

\subsection{Conceptual Data Model}

Although this project did not require a single integrated database, based on the User Needs Assessment, the Ala Kahakai National Historic Trail staff did have a need for an organized, stable, and reliable set of data from which they could produce maps for various reports and outreach efforts and conduct some spatial analysis to assist with their management of trail resources. The Ala Kahakai NHT is divided into six management areas, bisected by over 200 ahupua'a, and crosses four national parks as well as much private land. Data needed to support the analysis would include land ownership, land use, and cultural resource proximity. Other data, including vegetation, trail infrastructure, and hydrology, would also be useful. These data need to be organized into various databases, keeping the large collections maintained by others separate from the trail data that the Ala Kahakai NHT would collect and maintain.

\subsection{Logical Data Model}

Most data were left in their native format in individual folders in order to adhere to different security access levels and update schedules. The University of Hawai' $i$, Department of Urban and Regional Planning (UHDURP) provided a collection of photos, maps, map footprints, and reports. The State Historic Preservation Division of the Department of Land and Natural Resources (SHPD) provided three versions of cultural resource data. The SHPD cultural resources features classes are joined to the tables by their site number and the UHDURP reports and images are joined to the footprints based on the report number. National Park Service's Hawai'i Volcanoes National Park Pacific West Region (PWR) database collection was downloaded and delivered as is to allow for easy updates based on their schedule. A new ALKA database was needed to collect data provided by park and other disparate sources. (Fig. 7) 


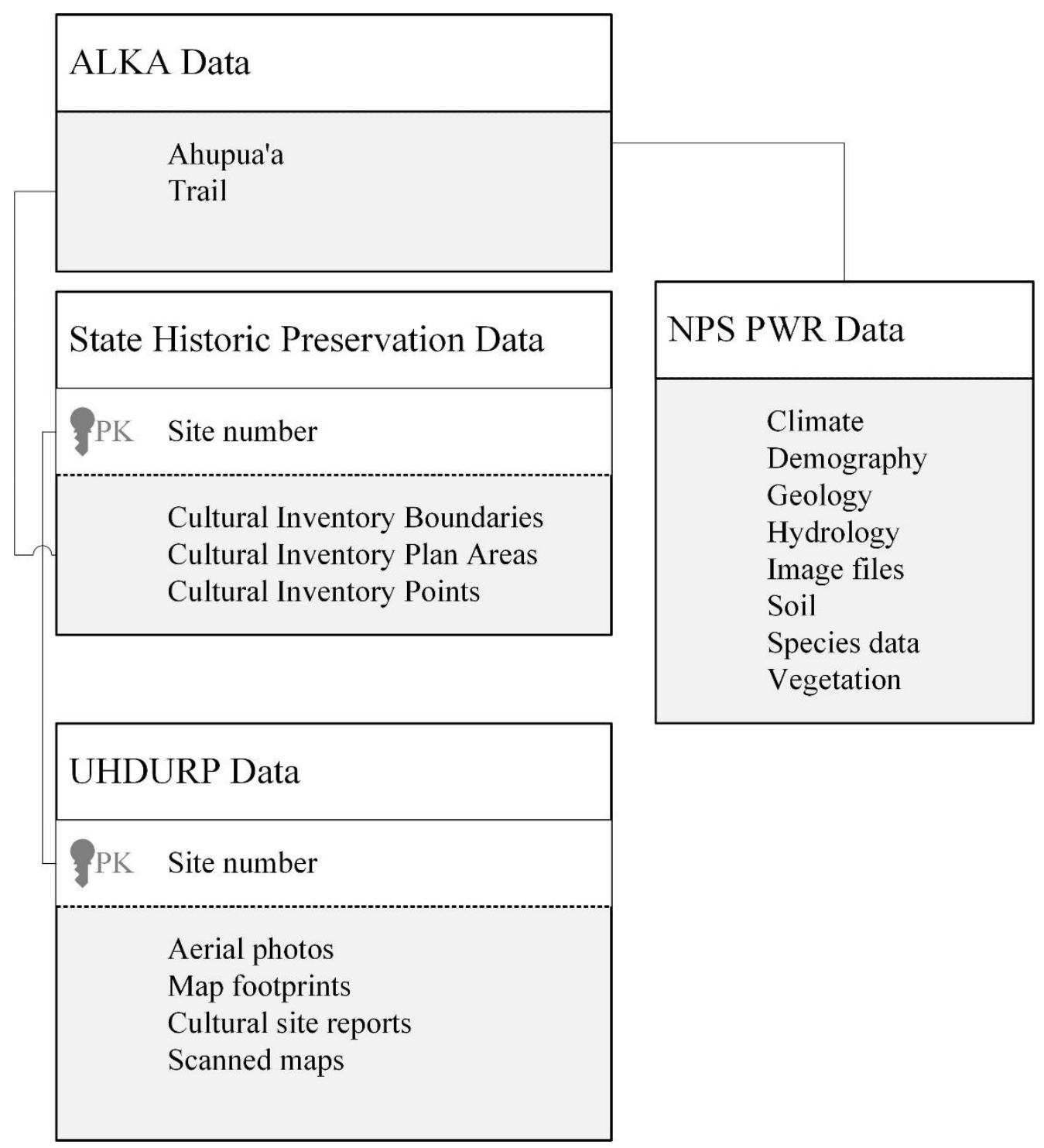

Figure 7 - Logical Model

\subsection{Data Sources}

\subsubsection{Minerbi Collection, UHDRP Data}

Dr. Minerbi (University of Hawai'i, Manoa) provided a collection of aerial photos, scanned maps, map footprints, reports and trail maps. GIS data were delivered with minimal metadata. Some of the Minerbi Collection was digitized as spatial footprints. The data were organized into the following archive:

- DISC1 - Registered (GCS_North_American_1983) aerial imagery of Hawai ${ }^{i}$, Honokaa, Kona, and Pahala (.tif)

- DISC2 - Registered (GCS_North_American_1983) aerial imagery of Hilo, Kawaihae, and Kohala (.tif) 
- DISC3 - The Trail to Ho'okena: Connecting Communities, Resources, Past, Present, and Future. PLAN 751 Spring 2008 Practicum, Department of Urban and Regional Planning, University of Hawai'i at Mānoa, Honolulu, Hawai' $i$

- DISC4 - Chapter 2 from UH DURP 2008: NPS Ala Kahakai National Historic Trail - Heritage Landscape and Trails: Unregistered maps of trails documented on historical maps, archaeological report footprint maps. The following is a list of the GIS data created by Dr. Minerbi and staff from historical maps and documents:

$\circ \quad$ Georeferenced historical maps (.tif)

- Footprints of the georeferenced historical maps

- $\quad$ Point features digitized from georeferenced historical maps

- Trails digitized from georeferenced historical maps

- Land Commission Award parcels digitized from georeferenced historical maps

- Footprints of archaeological reports

- GPS survey of trail from Kaohe to Kukuiopae

- DISC5 - Scanned Arch Reports for Ka'u, North Kona, South Kona and South Kohala

- DISC6 - Unregistered Bishop Estate maps (.tif), Bishop Museum maps (.pdf), Hawai'i Territorial Survey Plat Maps, Land Court maps, TMK maps, and Cancelled Tax Maps. Data documentation by Dr. Minerbi states the Reg folder contains registered maps, but spatial reference in undefined and these cannot be used at this time.

- DISC7 - Scanned Arch Reports for Ka'u, North Kona, South Kona and South Kohala

- DISC8 -Ahupua'a Boundary Documents, Land Commission Awards, and Land Ownership maps prepared by UH DURP, Māhele Database Documents.

\subsubsection{Cultural Data Collection}

Cultural data were acquired from the State Historic Preservation Division of the Department of Land and Natural Resources.

- Library folder- databases of various tables to be joined to spatial data

- Scans folder- Scans of site diagrams from culture reports

- SiteData folder- databases of various tables to be joined to spatial data

- GIS_data.mdb - Features classes of points, lines, and polygons

\subsubsection{PWR Databases}

National Park Service's Hawai'i Volcanoes National Park Pacific West Region (PWR) databases contain species, climate, geology, marine, soil, and vegetation data that were collected for the entire island and provided for NPS use. 


\subsubsection{ALKA Database}

The ALKA database was constructed from publicly available federal, state and county data, and includes the trail footprint and the ahupua'a land division polygons.

\subsection{Summary}

From four main sources, the system included 1412 imagery files and 409 raster and vectors files. Data from three of the sources; National Park Service's Hawai'i Volcanoes National Park Pacific West Region (PWR) database, State Historic Preservation Division of the Department of Land and Natural Resources database, and Dr. Minerbi's University of Hawai' $i$, Department of Urban and Regional Planning database were delivered to the client in the same basic structure as received in order to facilitate updates. Publicly available data was collected and organized with a standard naming convention in the ALKA database. 


\section{Chapter 6 - Implementation}

Minerbi, PWR, and Cultural data were provided by the client to be organized and checked for quality. State and county public data was downloaded and organized into a geodatabase to serve as base map and reference data. All data were reviewed and organized and returned to the client.

Table 1. Client Deliverables

\begin{tabular}{|l|l|}
\hline Deliverable & Description \\
\hline $\begin{array}{l}\text { Resourtographic } \\
\text { Data }\end{array}$ & ArcMap styles, legend symbols, logos \\
\hline & Organized data \\
\hline & PWR data - delivered to client as received \\
\hline & Cultural data - QC'd and cleaned \\
\hline Documents & $\begin{array}{l}\text { ALKA database - State/County data - organized personal database } \\
\text { with naming conventions }\end{array}$ \\
\hline & User Needs Assessment \& Requirements Analysis (NARA) \\
\hline & Data Inventory Report \\
\hline Maps & Cultural Data Assessment Report \\
\hline & $\begin{array}{l}\text { ArcMap templates that allow staff to evaluate the status of trail } \\
\text { sections and to graphically convey this information in reports and } \\
\text { public outreach efforts }\end{array}$ \\
\hline
\end{tabular}

\subsection{Non-spatial data inventory recommendations}

Ala Kahakai NHT staff have a desire to compile reference information for related documents, images and other information resources. This inventory (Table 2) could be done manually using Microsoft Excel, EndNote, or by accessing the embedded metadata using Voyager GIS. Inventories could also be maintained in an online collaborative environment like Google Docs, Microsoft SharePoint or Microsoft Office Live Workspace. This should follow some library catalog standard such as the US Library of Congress MARC, ISBD, or ISO 690. 
Table 2. Recommended of Non-spatial resources catalog fields

\begin{tabular}{|l|l|}
\hline Field Name & Definition \\
\hline Category & $\begin{array}{l}\text { Resource type (Reference Material, Planning Document, } \\
\text { Development Project, Open Space Initiative) }\end{array}$ \\
\hline Title & Resource Title \\
\hline Subject & Keyword \\
\hline Author(s) & Author or authoring institution \\
\hline Date & Publication Date \\
\hline Time Frame & $\begin{array}{l}\text { Time period to which the resource pertains (where no publication date } \\
\text { is given) }\end{array}$ \\
\hline Status & Pertains only to development projects and open space initiatives \\
\hline $\begin{array}{l}\text { Geographic } \\
\text { Location }\end{array}$ & Geographic reference to which the resource relates \\
\hline Abstract & Whether or not an abstract for the document or resource exists \\
\hline ID No. & Pertains only to development projects \\
\hline Contact & Name and phone number, where available, of relevant contact person \\
\hline $\begin{array}{l}\text { Document } \\
\text { Location }\end{array}$ & Physical location of the document or resource \\
\hline File Name & Digital file name of the document or resource \\
\hline Format & digital or hard copy \\
\hline Website & URL address for the resource, where available \\
\hline Description & Brief description of the resource \\
\hline
\end{tabular}

\subsection{GIS Data}

This project collected a set of 38 geodatabases from the National Park Service's Hawai'i Volcanoes National Park Pacific West Region, State Historic Preservation Division of the Department of Land and Natural Resources, and University of Hawai' $i$, Department of Urban and Regional Planning. Additional shapefiles and layer files, and an extensive collection of image files were organized, processed and delivered to the clients. A subset (19) of the databases was categorized as essential for ALKA management. The following sections present a summary of existing data which are being generated and/or maintained by the NPS, or which have been acquired by the ALKA team.

A data inventory was conducted to identify sources of existing spatial and nonspatial data that could be utilized for trail planning, trail management, resource protection, interpretation, and public outreach. Critical data sources include reference, base mapping, and cultural resource data. The National Park Service's Hawai'i Volcanoes National Park PWR database was determined to be the best-available source for much of the spatial data. Additional spatial data were identified and retrieved from other government agencies and educational facilities. Dr. Luciano Minerbi, University of Hawai' $i$, provided a set of cultural resources that included aerial photography, scanned maps, map footprints, reports and trail maps. 
A data inventory table was generated to describe more than 1,800 unique GIS datasets and raster images. The data were interpreted to add key data quality/characteristics (Abstract, Purpose, Access or Use Constraints, Scale, Currentness, Coordinate System, and Contact Information) to the inventory. A full list and description of data relevant to The Ala Kahakai NHT management can be found in the Data Inventory, which was provided to the TKC and NPS-ALKA team members. The following data were acquired from the client, reorganized, and returned.

\subsection{Cultural Data Collection}

Cultural data were acquired from the State Historic Preservation Division of the Department of Land and Natural Resources. Several updates made by ALKA staff were cross-checked and appended (duplicates were deleted). The assessment and processing of the cultural resource data reveal data quality issues: some data years were outdated, there were numerous duplicate records, there were multiple GIS records with the same identifier (site numbers) scattered about the island, and there were multiple GIS records that had a specific site number with a different State Identification Number. There was an attempt to quality control, clean, and resolve these issues where possible.

\subsection{Data Scrubbing and Loading}

Much of the data obtained were processed to improve their quality and utility for NPSALKA. Data were processed to comply with NPS quality, metadata, and organizational standards. The Ala Kahakai Trial line feature was integrated with the Ahupua'a boundaries to create subsections of the trail identifying trail stewardship.

Multiple datasets of cultural features (points, lines, and polygons) were compiled into three main feature classes. The HAVO data were processed and delivered as a collection of geodatabases designated PWR GIS. Data found in the HAVO Parks or Regions directories were not inventoried or assessed. The Parks databases contain data clipped to Kaloko-Honokohau National Historical Park. The Regions databases contain data grouped into American Samoa, Archipelago of the Commonwealth of the Northern Mariana Islands, Guam, and the State of Hawai' $i$. The NPS HAVO database is structured using the following themes. Note that this data will need to be updated manually on a regular basis from the HAVO server.

\subsection{Summary}

The data delivered to the client is being used and was in fact their only source when their entire system crashed. Unfortunately the cultural data were completely out of date with too many errors that it was not usable to associate with trail segments with any confidence. 



\section{Chapter 7 - Data Management Strategy}

The most costly and time consuming task in any GIS is the work involved in acquiring, processing, and performing quality control on the data. A well planned data management strategy helps to establish the various tasks needed maintain a GIS.

\subsubsection{Data Loading/Migration}

Once it had been determined that the data were appropriate for loading, the following steps were be followed (Fig. 8).

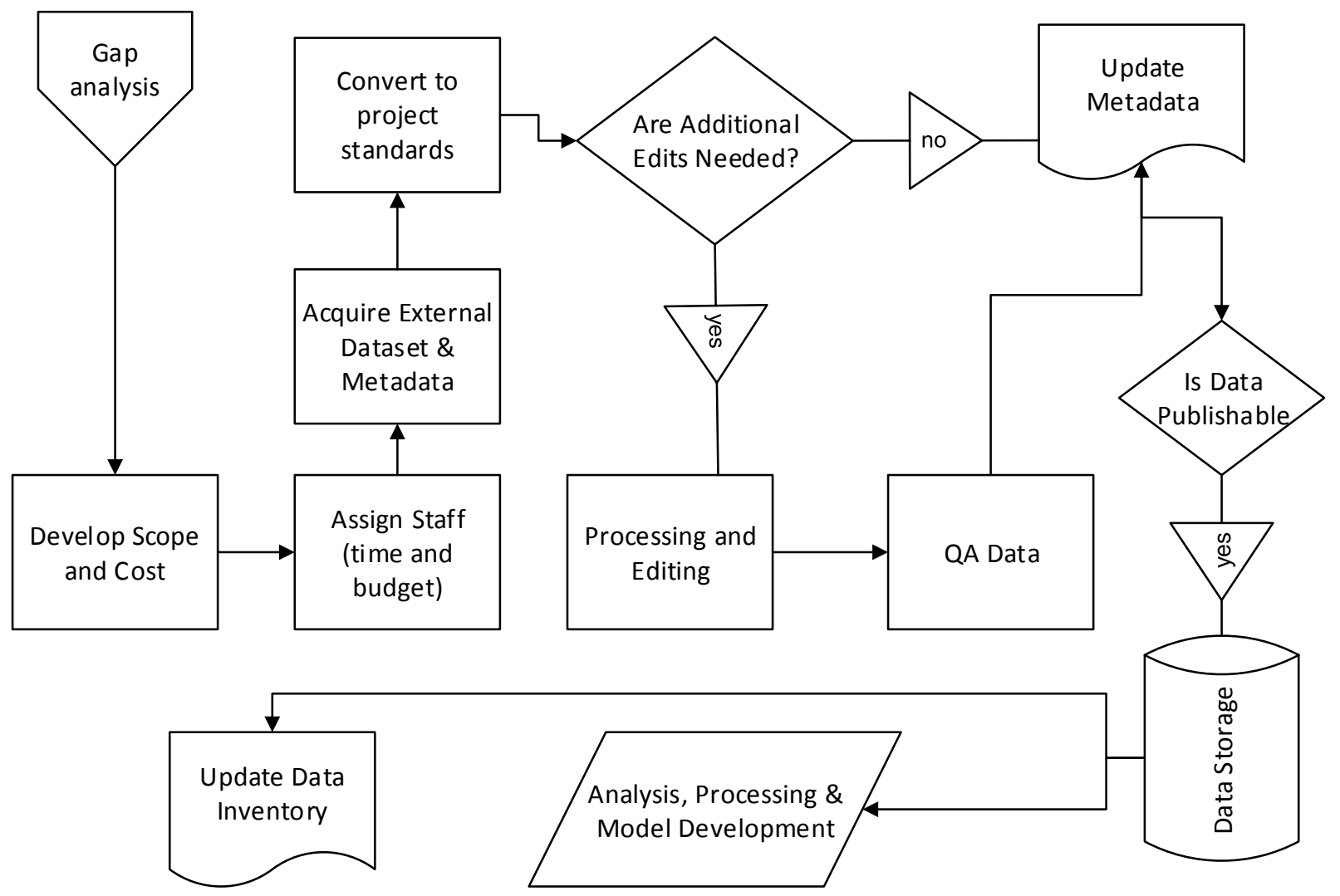

Figure 8 - Data Maintenance Workflow

- Convert data formats (the difficulty of this ranged from simple to difficult depending on the source format).

- Scrubbed bad data to remove or fix invalid data.

- Verified unique item value, valid value codes, table relationships, populated items, positional accuracy, connectivity, spelling, duplicates, and outliers.

- Reformated, reprojected, and renamed to meet agreed-upon standards.

- Loaded to final repository. 
- Applied or updated metadata to meet agreed-upon standards.

- Documented data repository structure and content.

- Inventoried the data repository using Microsoft Excel.

- Recommendations for future data inventory and structure documentation:

- Schema diagram of repository should be maintained. ArcGIS Diagrammer can be an appropriate tool for developing these diagrams.

- Voyager http://voyagergis.com/ may be used to maintain the inventory.

\subsubsection{Interoperability requirements}

Data was stored in format compatible with NPS standards.

http://irmafiles.nps.gov/reference/holding/152590

\subsubsection{File Naming Conventions and Directory Structure}

A clear and meaningful file name was used that conveys the nature of the data, subject, and park unit represented. Data and related file names did not contain spaces or special characters.

\subsubsection{Coordinate Systems}

All spatial data was geo-referenced with projection information defined in the data file. All spatial data was provided in the standard regional-scale projection(s). Parklevel data used UTM and NAD83 whereas regional- or national-level data used decimal degrees (double precision with five or more significant digits) and NAD83.

\subsubsection{Spatial Data Formats}

Spatial data formats supported include:

- ESRI Arc Info Coverage/export file

- ESRI Shapefile

- ESRI ArcGIS Geodatabase

- ESRI ArcGIS File Based Geodatabase

- Arc Info GRID File

- ERDAS Imagine file

- GeoTIFF v1.0

- TIFF (will include world files)

\subsubsection{Security requirements}

Data will be secure to NPS staff. All data and analysis products will be kept on desktop computers accessible only to NPS staff and consultants. The data will not be posted online to any web or GIS data service. 


\subsubsection{File hierarchies}

The following network file hierarchy was recommended:

- $\quad$ Cartography - this network folder will contain ArcMap_SymbolLibrary, ArcMap_Styles, Carto Web Sites, Legend_Symbols, Logos, TricksAndStuff

- Data - if the source data organization structure is not chosen to be maintained, the following network folder hierarchy is recommended.

$\begin{array}{ll}\circ & \text { Administrative } \\ \circ & \text { CoastalMarine } \\ \circ & \text { Cultural } \\ \circ & \text { Hazard } \\ \circ & \text { Imagery } \\ \circ & \text { NaturalResources } \\ \circ & \text { PhysicalFeatures }\end{array}$

- Documents - this network folder will contain Ala Kahakai management documents, background research, and NPS reports

- Maps - the maps network folder will contain all historic and land planning maps as well as ArcMap templates

- Photos

\subsection{Data Access Options}

This task is purpose-driven, as there is rarely one solution. A sharing solution for a central repository for all relevant data may be very different than delivering specific analysis project data and analysis results.

\subsubsection{Access to Source Data}

The client needed to access the data through four main mechanisms; local data access, FTP, ArcGIS, and third party applications.

Local data access - Provide direct access for authenticated domain users to repositories through folder shares and/or database authentication. Users must be on-site or connected to the network via VPN to access the files.

FTP/HTTP data access - Provide access to shapefiles with FTP or HTTP authentication, often with a simple website for browsing data holdings. This can be difficult to keep up-to-date with regularly-updated data because new data holdings must be updated within the website/catalog (usually manually). This is how the State GIS site is maintained.

ArcGIS.com - Esri now allows users to host data in their cloud infrastructure, called ArcGIS.com (formerly called ArcGIS Online). This allows users to upload layer packages for download by other users. There is a group-based security model setup to allow users to control who can see and access the files. There is a data upload limit but not many details have been released as the solution is still in private beta. 
Applications (such as Voyager) - Extracts data from the data repository and delivers it to the client in any number of formats. These applications usually provide a front end for browsing and searching data holdings and generally allow for automated selection, clipping, and compression of the data (clip, zip, \& ship) to the user.

\subsection{Summary}

This chapter outlined a recommended data management strategy that would allow the Ala Kahakai NHT staff to maintain the data with confidence applying naming conventions, standard projections, geometry and attribute accuracy, and network organization. 


\section{Chapter 8 - ALKA Map Templates \& Cartography}

\subsection{Map Templates}

NPS standard map templates were downloaded and adapted for use with trail-related data. As these templates meet the National Park Service standard, they should not be changed significantly. The legend, scale bar, and north arrow placements are all meant to be flexible. The master map template contains all project data which has been symbolized. Other templates are:

- $8.5 \times 11$ - portrait and landscape

- $11 \times 17$ - portrait and landscape

- D \& E size - portrait and landscape

Templates were delivered in a folder structure which also includes a directory of ArcMap symbol styles, NPS logos, map tips, and links to map-based web services.

The NPS Rawlinson and Frutiger typefaces approved for the Graphics Identity

Program do not appear on the list of fonts available within ArcGIS. If the Rawlinson and Frutiger fonts are not currently installed on the computer, it is suggested to substitute the Garamond Bold typeface in place of Rawlinson font and Arial Bold or Arial in place of the Frutiger typeface. These fonts are included in the data deliverable or can be downloaded from the NPS Graphics Identity Program at http://www.graphics.nps.gov/templates/fonts.htm.

It is important to note that when these Map Template Files (.mxt) are opened in ArcMap, any changes will be saved to a new Map Document File (.mxd) and will not modify the original Map Template File. Additional map examples are found in Appendix D.

NPS map template requirements (Fig. 9) included a top black band with park name, NPS identification and logo. The bottom band includes the date, author, and purpose. All maps will include a title, north arrow and scale bar. 


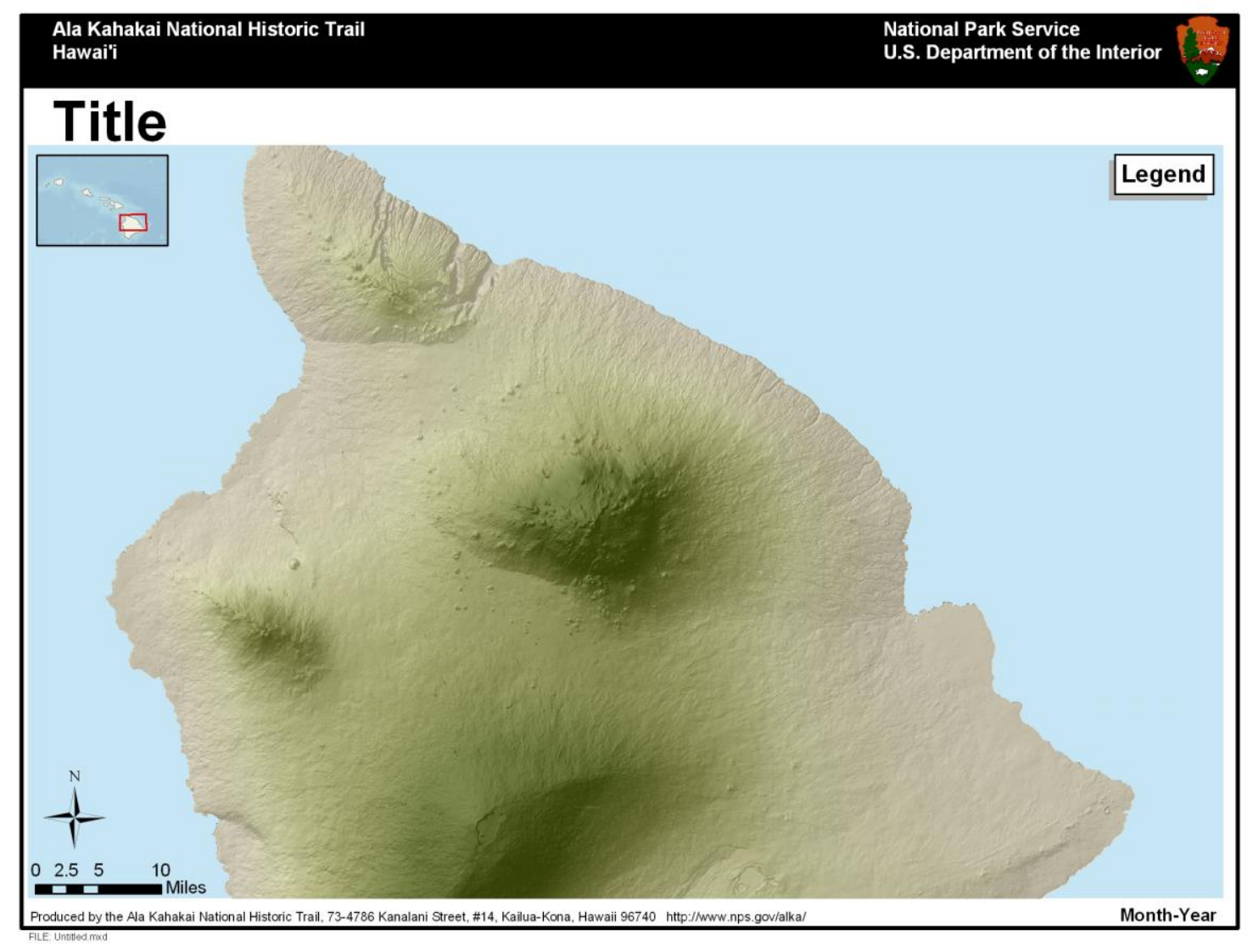

Figure 9 - Map template

\subsection{Cartographic Resources}

A number of ArcMap templates were developed to allow staff to quickly evaluate the status of trail sections and to convey this information graphically in reports and public outreach efforts. Standard symbology stored as ArcMap symbology style files (.style) allow for easy modifications as data are updated.

\subsection{Summary}

ArcMap templates were produced using NPS symbol styles, logos and fonts to have a consistent and NPS compliant format for reporting and outreach efforts. 


\section{Chapter 9 - Conclusions and Future Work}

The goal of this project was to provide the Ala Kahakai NHT staff with an organized database, data standards, maps templates, and a methodology to continue to comply with the goals of the Ala Kahakai National Historic Trail Comprehensive Management Plan. All documents and data were delivered to the client in November 2008 as scheduled and have been used since. The cultural data was out of date and contained many spatial and attribute errors. The data was of insufficient quality to be able to associate it with trail segments with any confidence and the State Historic Preservation Division of the Department of Land and Natural Resources were notified.

Several years passed between the completion of the project work and the defense of this MIP. Even though core data management methodology has not changed significantly, GIS and other technology has. It is recommended that before additional research and collaboration with the Ala Kahakai National Historic Trail is perused, that a new review of available data hosting and sharing services be explored.

Additionally, great advances have been made in the acceptance of and technology for indigenous mapping. A thorough literature review which includes this should be conducted.

\subsection{Recommendations}

Recommendations to staff on using GIS for management, community involvement, and public outreach include developing tools/workflows to help in daily use of GIS by staff for routine management, developing tools/ workflows to help staff engage local community and agencies. It is also recommended that routine state and county data updates are downloaded annually, trail assets such as educational kiosks and benches be inventoried and the locations digitized, and every effort should be made to work with the Hawaii State Historical Preservation Office to correctly locate and map all cultural and historic resources within close proximity to the trail.

\subsection{Future Work}

Future work could include working with the Hawaii State Historical Preservation Office to inventory and map all cultural and historic resources within close proximity to the trail. To accommodate the Land Development Process Tracking Tool being developed, a MIP could be developed with the County permitting office to develop an online permit tracking application with mechanism to search and track all permits, and their status, in proximity to the trail.

\subsection{NPS Contract}

In August 2009, The Redlands Institute was awarded a contract to support the development and management of the National Park Service (NPS) Ala Kahakai National 
Historic Trail. The proposed project involved the development and integration of three modules: a Knowledge Management System, a Land Development Process Tracking Tool, and a Trail Planning and Management Tool. These modules will be integrated with the Park Service's Geographic Information System (GIS) to leverage and extend their existing infrastructure and capacity. The work done for this report will be integrated into the ALKA Land Development Process Tracking Tool, and the Trail Planning and Management Tool. 


\section{Works Cited}

Ahupua'a. (n.d.). Retrieved 2008, from Wikipedia: http://en.wikipedia.org/wiki/Ahupua'a

Ala Kahakai National Historic Trail Planning Team. (2004). PLANNING UPDATE:

Draft Management Prescriptions and Alternatives.

ArcGIS Diagrammer. Retrieved 2008, from

http://arcscripts.esri.com/details.asp?dbid=15166

Chambers,K., et al. (2004). Indigenous Knowledge, Mapping and GIS: A Diffusion of Inovation Perspective. Cartogrgaphia , 39 (3), 19-31.

Chapin, M., Lamb, Z., \& Threlked, B. (2005). Mapping indigenous lands. Annual Review of Anthropology, 34, 619-638.

Dicus, G. H. (2006). Data Management Plan for the Pacific Island Network. Retrieved October 2007, from National Park Service Inventory \& Monitoring Program: http://www1.nature.nps.gov/im/units/pacn/data/PACN_data-mgmt-plan.pdf

Greene, L. W. (1993). Figure 8, Drawing of an ahupua'a. Retrieved September 2009, from A Cultural History of Three Traditional Hawaiian Sites on the West Coast of Hawai'i Island: http://www.nps.gov/history/history/online_books/kona/fig8.jpg

Hamabata, M. (2006). The Kohala Center \& Redlands Institute, Confidential Concept Paper for Kohala Center GIS Infrastructure.

HaySmith, L. F. (2005). Pacific Island Network Vital Signs Monitoring Plan. Fort Collins, Colorado: National Park Service.

Kemp, K. (2007, October 4). (L. Benvenuti, Interviewer)

Louis, R. P. (2004). Indigenous Hawaiian Cartographer: In Search Of Common Ground. Cartographic Perspectives (48), 7-23.

Mauna Kea Visitor Information Station. (2006, April 3). Retrieved September 27, 2007, from

http://72.14.253.104/search?q=cache:fkZKYtzcq24J:mkooc.org/S_Talks/S_04030 6_CFH.doc+Aric+Arakaki\&hl=en\&ct=clnk\&cd=2\&gl=us

Mind Tools Ltd. (2007). Cost/Benefit Analysis Evaluating Quantitatively Whether to Follow a Course of Action. Retrieved 11 2, 2007, from http://www.mindtools.com/pages/article/newTED_08.htm

National Park Service, U.S. Department of the Interior. (2006a). The National Trails System Memorandum of Understanding.

National Park Service, U.S. Department of the Interior. (2006b). GIS standards. http://science.nature.nps.gov/nrgis/pdfs/NPS_GISSpecs_20070302.pdf

National Park Service, U.S. Department of the Interior. (2007). Ala Kahakai National Historic Trail. Retrieved September 25, 2007, from http://www.nps.gov/alka/Tripathi, N., \& Bhattarya, S. (2004, April). Integrating Indigenous Knowledge and GIS for Participatory Natural Resource Management: State-of-the-Practice. Retrieved October 2, 2007, from The Electronic Journal of Information Systems in Developing Countries:

http://www.ejisdc.org/ojs2/index.php/ejisdc

University of Redlands, MSGIS. (2006, October 14). Karen K. Kemp. Retrieved October 10, 2007, from http://www.institute.redlands.edu/kemp/

Voyager. Retrieved 2008, from http://voyagergis.com/ 



\title{
Appendix A. Needs Assessment
}

\author{
ALKA GIS User Needs - Karen Kemp \\ Report from meeting June 25, 2008 with Aric Arakaki and Rick Gmirkin \\ 1. ALKA Business Processes (relevant to GIS use) \\ 1.1. Planning for trail administration, development and management - make informed \\ and timely decisions regarding trail alignment, evaluate compliance to regulations and \\ permits of shoreline developments, locate historic trail segments protected or not \\ protected under Highways Act, determine location of cultural and natural features that \\ will be affected by use of the trail, determine owners so they can be engaged in the \\ planning process
}

1.1.1. Land use planning - development of Environmental and Cultural Impact statements, engage public in the development of statements and plans

1.1.2. Trail planning - includes landscape planning, precise trail alignment on the ground, slopes, location of parking, access, toilets, and other amenities, identification and management of safety issues

1.2. NPS trail management, inventory and monitoring (I\&M) activities - inventory of cultural and natural resources, monitoring impacts of trail use and access on cultural and natural resources, planning for management activities such as herbicide use, managing trail segment closures, determining trail carrying capacity (both environmental and spiritual)

1.3. Public Outreach - general public education, orientation to where things are, provision of information about trail access, features, hazards, and safety

1.4. Support trail segment management entities (TSMEs, or "segment managers") share knowledge and learn more about their land, give access to information they didn't have previously, assist them to report trail corridor problems and issues, support their I\&M activities (need both digital and hard copy)

2. Users of ALKA GIS resources

2.1. Families - own their data, only make available what they choose to

2.2. Segment managers - to record and report where natural resources are, to use information to restore the cultural landscape, report problems and issues of use along the segment. Note that TSMEs will need to have an easy and efficient way to communicate this information to NPS and this information will need to be vetted, reviewed, flagged for follow-up and stored as appropriate.

2.3. Visiting public - to get information about trail access, hours, visitor resources, stories, safety issues, etc.

2.4. General public - to learn more about the landscape and people of Hawai' $i$ (web access - see for example. http://www.nps.gov/juba)

2.5. NPS - trail administration, management and oversight, support all others

3. Map and digital output needed

3.1. Presentations (includes PowerPoint and posters)

3.2. Reports (includes maps in folio, landscape and portrait size and data summaries as charts and graphs)

3.3. Maps and analytical tools to be used as management tools

3.4. Maps and website to be used as tools for public input

4. Analysis needed 
4.1. Buffers, densities, slope, use counts (from automated sensors)

4.2. I\&M indicators

4.3. Change detection

4.4. Many others not yet identified

5. Data and System Issues

5.1. All processes require easy and efficient access to lots of available spatial and spatially- related data such as scanned maps and reports

5.2. A master table which records the status of each stage in development for each trail segment is needed

5.3. Requires the establishment of trail segments and their IDs

5.3.1. Smallest unit of trail is determined by individual parcel boundaries

5.3.2. In many cases a single owner will have several contiguous parcels

5.3.3. In some cases, a logical aggregation of parcels is possible (e.g. along Ali'i Drive in Kailua)

5.3.4. Initial unique IDs for segments can be based on Ahupua'a names extracted from state provided shapefile and refined by Aric and Rick, making decisions where some ahupua'a segments may need to be split or aggregated, ensuring that the assigned name is appropriate for use as an ID

5.3.5. Segments names and boundaries must be permitted to change over time, so a delta table will be needed to record these changes and to ensure that references to prior names can be linked

5.4. Kinds of ownership and use controls relevant to trail management include

5.4.1. State owned (DHHL, State Parks, DLNR + leases on all of these)

5.4.2. Federal lands (mostly NPS)

5.4.3. Large private landowners (includes Kamehameha Schools, Queen Lilioukalani

Trust., major developers and resorts, etc.).

5.4.4. State owned or managed trail easements on private land

5.4.5. Lateral access conditions/constraints as required/defined by County development permits

5.4.6. Public shoreline access

5.5. Need protocols for incoming data collected by public, segment managers and possibly families 


\section{Appendix B. Geodatabase Standards}

Attribute Domains

Attribute fields for each feature will be reviewed for completeness.

Topology Rules

Parcels will not overlap; parcel data will not have slivers.

Scale

Resolution

Data will be acquired at best scale available.

DEM data $<=30 \mathrm{~m}$

Precision/Tolerances

Fuzzy $1.00 \mathrm{~m}$

Weed $0.01 \mathrm{~m}$

Grain $0.01 \mathrm{~m}$

Node snap $1.00 \mathrm{~m}$

Snap $1.00 \mathrm{~m}$

Dangle $0.00 \mathrm{~m}$

Projection/Datum

Data should be stored in the database primarily in standard UTM Zone 4 meterbased NAD 1983 coordinate system. Projection and transform processing should be kept to an absolute minimum. Data should pass through only two coordinate systems: the original projection and coordination, and the project standard.

Data Standards

For shape files, features can be points, lines or polygons. Polygon coverages will be permitted no label errors, dangle errors, or intersection errors. All polygons will have labels, and codes in attribute fields will be identified in metadata.

Data Sources

When possible, data will be acquired from NPS or state sources.

Data Format

Geospatial data in shape file format, info coverages or geodatabase files can all be accommodated. Excel and access databases can be imported.

Metadata

Metadata will be FGDC \& NPS compliant. Metadata will be written using the ArcCatalog interface with all required fields completed as a minimum standard. In addition, all code in attribute fields will be documented.

Topology requirements

All data conflicts between adjacent tiles must be addressed.

Product output requirements

Digital map output in image or pdf format. 
Maintenance requirements

Base data will be update following state updates. Cultural data will be updated as often as possible.

QA/QC

Unique Item Value, Valid Value Codes, Table Relationships, Populated Items, Positional Accuracy, Connectivity, Spelling 


\section{Appendix C. Delivered Hard Drive Data Structure}

\begin{tabular}{|c|c|c|}
\hline $\begin{array}{l}\text { ALAKAHAKAI } \\
\text { FOLDER } \\
\text { STRUCTURE }\end{array}$ & (SUBFOLDER) & CONTENTS \\
\hline Cartography & AcrMap_SymbolLibrary & Pdf's of ArcMap symbology styles \\
\hline Cartography & ArcMap_Styles & ArcMap symbology style files (.style) \\
\hline Cartography & Carto Web Sites & List of and links to helpful cartography websites \\
\hline Cartography & Legend_Symbols & Legend background.bmp \\
\hline Cartography & Logos & NPS logos \\
\hline Cartography & TricksAndStuff & Useful ArcMap tricks \\
\hline GIS & GIS & RI generated database, SHPO data \\
\hline GIS & Imagery & DRG, Lidar, 10m DEM, Ortho Photos \\
\hline GIS & ImageServers & Links to Image Servers as layer files \\
\hline GIS & MetadataDocs & $\begin{array}{l}\text { Pdf's and word doc (FGDC Required Metadata } \\
\text { Elements, MetadataQuickQuide, } \\
\text { top10metadataerrors, Metadata in ArcCatalog, GIS } \\
\text { Glossary) }\end{array}$ \\
\hline GIS & PWR_GIS & $\begin{array}{l}\text { NPS service data for Hawai'i (layer files, rasters and } \\
\text { vector geodatabases) }\end{array}$ \\
\hline GIS & & $\begin{array}{l}\text { Islands - Climate.mdb, Demography.mdb, } \\
\text { Ecoregions.mdb, } \\
\text { ElectronicNauticalCharts_NOAA.mdb, } \\
\text { GeodeticSurvey.mdb, Geology.mdb, Hazards.mdb, } \\
\text { Hydrography.mdb, LandManagement.mdb, } \\
\text { Marine.mdb, Soil.mdb, Topography.mdb, } \\
\text { Vegetation.mdb }\end{array}$ \\
\hline GIS & & Parks - data for KAHO only \\
\hline GIS & & $\begin{array}{l}\text { Regions - American Samoa, American Samoa, } \\
\text { ESRI Data \& Maps and StreetMap USA, ESRI } \\
\text { Image Data, Global Imagery, Guam, Hawai`i i State, } \\
\text { NPS I\&M Networks, Ocean }\end{array}$ \\
\hline GIS & Theme Manager & NPS Theme Manager \\
\hline GIS & Web Sources & List of and links to data websites \\
\hline
\end{tabular}




\begin{tabular}{|l|l|l|}
\hline $\begin{array}{l}\text { ALAKAHAKAI } \\
\text { STRUCRURE }\end{array}$ & (SUBFOLDER) & CONTENTS \\
\hline Documents & Ala Kahakai & $\begin{array}{l}\text { Draft Comprehensive Management Plan, Ala } \\
\text { Kahakai User Needs Assessment }\end{array}$ \\
\hline Documents & Background & $\begin{array}{l}\text { Background material on Indigenous Knowledge } \\
\text { Mapping }\end{array}$ \\
\hline Documents & NPS & $\begin{array}{l}\text { Graphics Identity Program documents, PACN } \\
\text { Monitoring Plan, }\end{array}$ \\
\hline Documents & Project Docs & RI project management documents \\
\hline Maps & ArcMap Images & Various ArcMap images (author L. Benvenuti) \\
\hline Maps & ArcMapTemplates & ArcMap templates based on NPS standards \\
\hline Maps & BI Park Maps & Ala Kahakai Trail maps (unknown author) \\
\hline Maps & Corridor Maps & Ala Kahakai Corridor maps (unknown author) \\
\hline Maps & Historic Maps & Miscellaneous map images \\
\hline Maps & Management zones & $\begin{array}{l}\text { Ala Kahakai Trail Management Zones (unknown } \\
\text { author) }\end{array}$ \\
\hline Maps & Misc Graphics & $\begin{array}{l}\text { Miscellaneous map images } \\
\text { etc. adjacent to trail }\end{array}$ \\
\hline Maps & Scans of cultural site areas \\
\hline Maps & Slans depicting marine managed areas, public \\
\hline
\end{tabular}




\section{Appendix D. Map Template Examples}

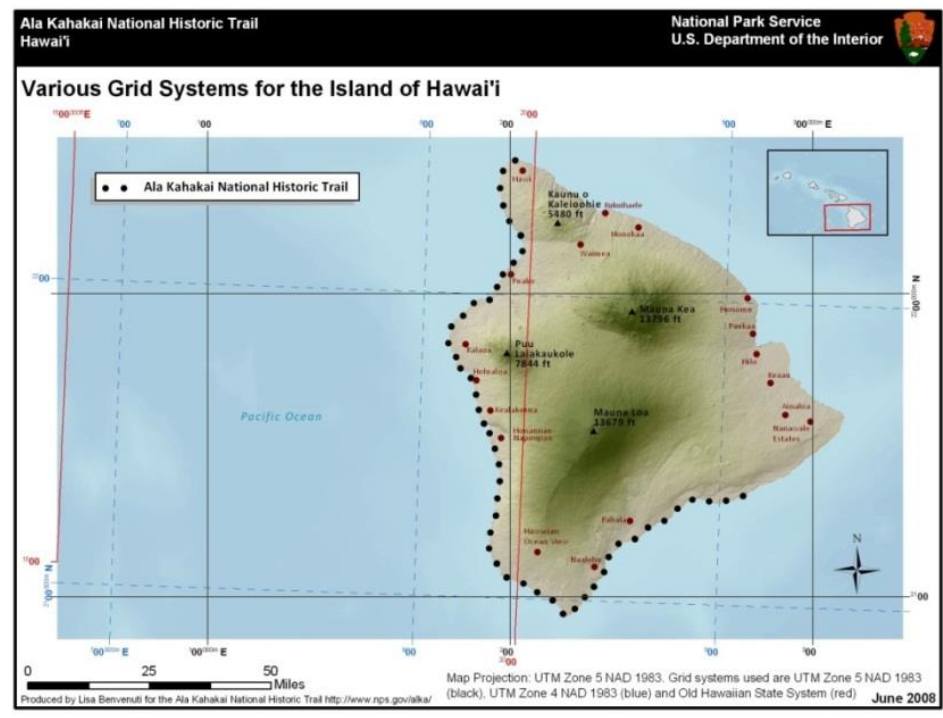

Figure D1 - $8.5 \times 11$ horizontal template showing the various grid systems for Hawai'i

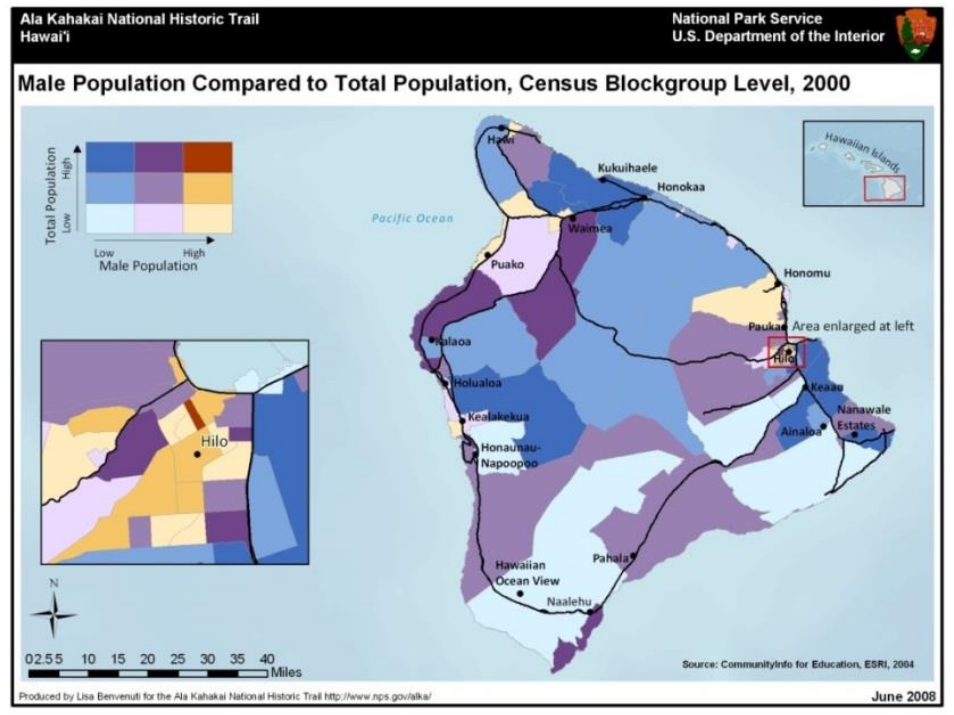

Figure D2 - $8.5 \times 11$ horizontal template showing male population compared to the total population at the census block group level 


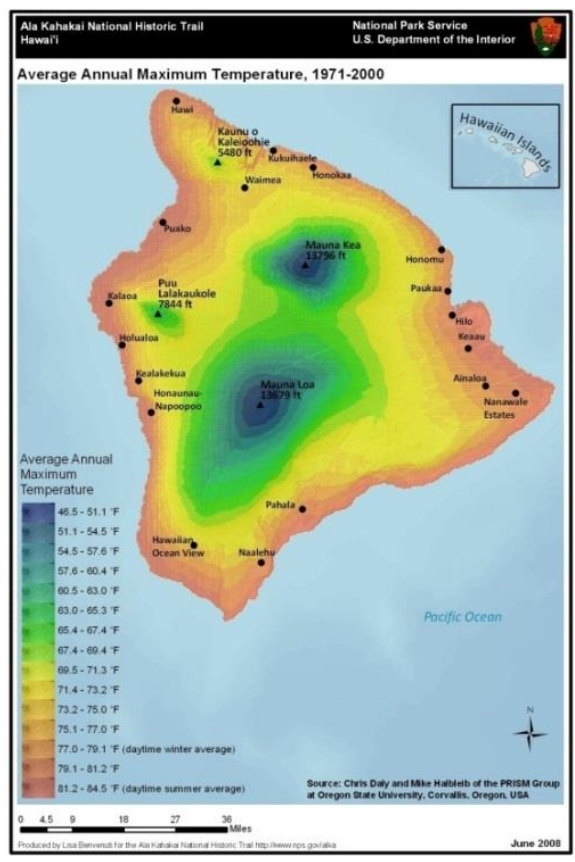

Figure D3 - $8.5 \times 11$ vertical template showing the average annual maximum temperature

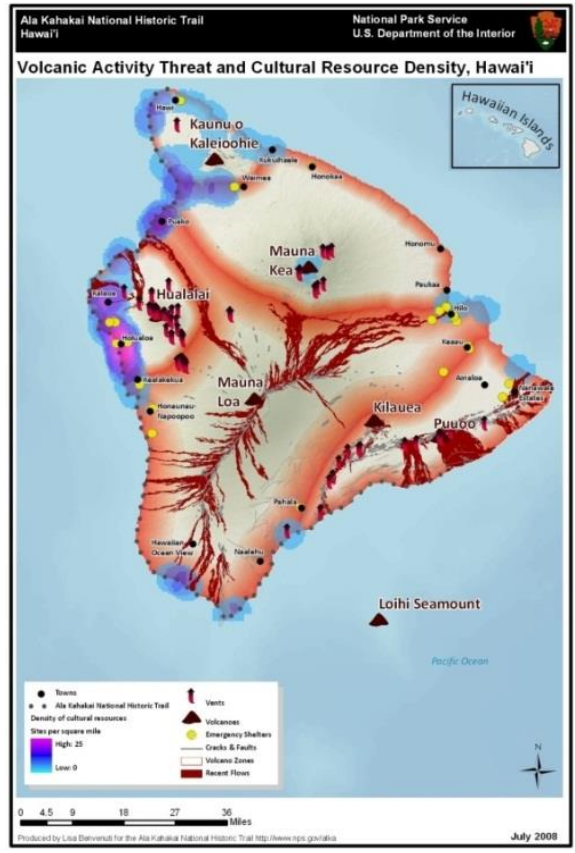

Figure D4 - $8.5 \times 11$ vertical template showing the density of cultural resources and their proximity to volcanic activity threat 


\section{Appendix E. Simplified Example of the Data Inventory}

\begin{tabular}{|c|c|c|c|c|c|c|c|c|c|c|c|c|}
\hline Name & Title & Geometry & ThemeKwr & Abstract & Purpose & AccConst & UseConst & Currentn & SrcScale & Projection & Originator & PubDate \\
\hline HA_FMA & $\begin{array}{l}\text { Fisheries } \\
\text { Management } \\
\text { Areas }\end{array}$ & $\begin{array}{l}\text { Vector - } \\
\text { Polygon }\end{array}$ & $\begin{array}{l}\text { inlandWaters } \\
\text {, location }\end{array}$ & $\begin{array}{l}\text { Locations of } \\
\text { fisheries } \\
\text { management } \\
\text { areas }\end{array}$ & $\begin{array}{l}\text { This data is } \\
\text { intended for } \\
\text { geographic } \\
\text { display and } \\
\text { analysis. }\end{array}$ & none & none & $\begin{array}{l}\text { publication } \\
\text { date }\end{array}$ & 100,000 & $\begin{array}{l}\text { NAD_1983_ } \\
\text { UTM_Zone } \\
\text { _ } 5 \mathrm{~N}\end{array}$ & $\begin{array}{l}\text { Office of } \\
\text { Planning, } \\
\text { State of } \\
\text { Hawaii }\end{array}$ & 1994 \\
\hline $\begin{array}{l}\text { HA_GovOwn } \\
\text { ership }\end{array}$ & $\begin{array}{l}\text { Government } \\
\text { Land } \\
\text { Ownership }\end{array}$ & $\begin{array}{l}\text { Vector - } \\
\text { Polygon }\end{array}$ & $\begin{array}{l}\text { Government } \\
\text { Land } \\
\text { Ownership, } \\
\text { Boundary, } \\
\text { planningCad } \\
\text { astre }\end{array}$ & $\begin{array}{l}\text { Government } \\
\text { Land } \\
\text { Ownership of } \\
\text { the State of } \\
\text { Hawaii }\end{array}$ & $\begin{array}{l}\text { To identify } \\
\text { Government } \\
\text { Lands in } \\
\text { Hawaii }\end{array}$ & $\begin{array}{l}\text { Public } \\
\text { data }\end{array}$ & $\begin{array}{l}\text { Public } \\
\text { data }\end{array}$ & $\begin{array}{l}\text { publication } \\
\text { date }\end{array}$ & 100,000 & $\begin{array}{l}\text { NAD_1983_ } \\
\text { UTM_Zone } \\
\text { _ } 5 \mathrm{~N}\end{array}$ & $\begin{array}{l}\text { Office of } \\
\text { Planning, } \\
\text { DBEDT, } \\
\text { State of } \\
\text { Hawaii }\end{array}$ & August 2006 \\
\hline $\begin{array}{l}\text { HA_Historic } \\
\text { Trails }\end{array}$ & $\begin{array}{l}\text { Na Ala Hele } \\
\text { State Trails } \\
\text { and Access } \\
\text { System }\end{array}$ & $\begin{array}{l}\text { Vector - } \\
\text { Polyline }\end{array}$ & trails & $\begin{array}{l}\text { Public trails } \\
\text { within the Na } \\
\text { Ala Hele Trail } \\
\text { and Access } \\
\text { system }\end{array}$ & $\begin{array}{l}\text { No Purpose } \\
\text { Provided }\end{array}$ & none & none & $\begin{array}{l}\text { publication } \\
\text { date }\end{array}$ & $\begin{array}{l}\text { No source } \\
\text { scale } \\
\text { information } \\
\text { provided }\end{array}$ & $\begin{array}{l}\text { NAD_1983_ } \\
\text { UTM_Zone } \\
\text { _ } 5 \mathrm{~N}\end{array}$ & $\begin{array}{l}\text { Office of } \\
\text { Planning, } \\
\text { State of } \\
\text { Hawaii }\end{array}$ & Unknown \\
\hline $\begin{array}{l}\text { HA_homela } \\
\text { nd500 }\end{array}$ & $\begin{array}{l}2000 \text { Census } \\
\text { Hawaiian } \\
\text { Homelands }\end{array}$ & $\begin{array}{l}\text { Vector - } \\
\text { Polygon }\end{array}$ & boundaries & $\begin{array}{l}2000 \text { Census } \\
\text { Hawaiian } \\
\text { Homelands }\end{array}$ & $\begin{array}{l}\text { This data is } \\
\text { intended for } \\
\text { geographic } \\
\text { display and } \\
\text { analysis. }\end{array}$ & none & none & $\begin{array}{l}\text { publication } \\
\text { date }\end{array}$ & 100,000 & $\begin{array}{l}\text { NAD_1983_ } \\
\text { UTM_Zone } \\
\text { _ } 5 \mathrm{~N}\end{array}$ & $\begin{array}{l}\text { Office of } \\
\text { Planning, } \\
\text { State of } \\
\text { Hawaii }\end{array}$ & 2000 \\
\hline $\begin{array}{l}\text { HA_Nationa } \\
\text { IParks }\end{array}$ & $\begin{array}{l}\text { Reserves of } \\
\text { Hawaii } \\
\text { Island } \\
\text { (updated } \\
\text { 2006) }\end{array}$ & $\begin{array}{l}\text { Vector - } \\
\text { Polygon }\end{array}$ & $\begin{array}{l}\text { Preserves, } \\
\text { Reserves, } \\
\text { Parks }\end{array}$ & $\begin{array}{l}\text { This data set } \\
\text { accurately } \\
\text { represents the } \\
\text { reserves, } \\
\text { preserves, } \\
\text { parks, etc. on } \\
\text { Hawaii Island. }\end{array}$ & $\begin{array}{l}\text { To accurately } \\
\text { represent } \\
\text { the reserves, } \\
\text { preserves, } \\
\text { parks, etc. on } \\
\text { Hawaii } \\
\text { Island }\end{array}$ & None & None & $\begin{array}{l}\text { publication } \\
\text { date }\end{array}$ & $\begin{array}{l}\text { No source } \\
\text { scale } \\
\text { information } \\
\text { provided }\end{array}$ & $\begin{array}{l}\text { NAD_1983_ } \\
\text { UTM_Zone } \\
\text { _5N }\end{array}$ & $\begin{array}{l}\text { National } \\
\text { Park Service }\end{array}$ & 2006 \\
\hline $\begin{array}{l}\text { HA_volcano } \\
\text { es }\end{array}$ & $\begin{array}{l}\text { US } \\
\text { Volcanoes }\end{array}$ & $\begin{array}{l}\text { Vector- } \\
\text { Point }\end{array}$ & $\begin{array}{l}\text { volcanoes, } \\
\text { eruptions }\end{array}$ & $\begin{array}{l}\text { This data set } \\
\text { includes } \\
\text { volcanoes } \\
\text { thought to be } \\
\text { active in the } \\
\text { last } \\
10,000 \text { years, in } \\
\text { and near the } \\
\text { United States. }\end{array}$ & $\begin{array}{l}\text { The digital } \\
\text { data sets of } \\
\text { the National } \\
\text { Atlas are } \\
\text { used to } \\
\text { create } \\
\text { electronic } \\
\text { and hard } \\
\text { copy maps } \\
\text { that depict } \\
\text { various } \\
\text { aspects of } \\
\text { the nation. }\end{array}$ & None & None & $\begin{array}{l}\text { publication } \\
\text { date }\end{array}$ & $2,000,000$ & $\begin{array}{l}\text { NAD_1983_ } \\
\text { UTM_Zone } \\
\text { _5N }\end{array}$ & $\begin{array}{l}\text { U.S. } \\
\text { Geological } \\
\text { Survey }\end{array}$ & 1996 \\
\hline
\end{tabular}

\section{Figure E1 - Data Inventory Example}

